\title{
Geologia, petrografia e geoquímica do Leucogranodiorito Pantanal e dos leucogranitos arqueanos da área a norte de Sapucaia, Província Carajás, Pará: implicações petrogenéticas \\ Geology, petrography and geochemistry of Pantanal Leucogranodiorite and archean leucogranites of the area north of Sapucaia, Carajás Province, Pará: petrogenetic implications
}

\author{
Mayara Fraeda Barbosa Teixeiral', Roberto Dall'Agnol', l, Alice Cunha da Silval', Patrick Araujo dos Santos \\ Universidade Federal do Pará. Belém, Pará, Brasil \\ "Instituto Tecnológico Vale. Belém, Pará, Brasil
}

\begin{abstract}
Resumo: Na porção leste do Subdomínio de Transição, porção sul do Domínio Carajás, afloram leucogranodioritos (Leucogranodiorito Pantanal), aparentemente alojados em uma associação TTG (Trondhjemito Colorado, 2,87 Ga) e seccionados em sua porção oeste por leucogranitos deformados. O Leucogranodiorito Pantanal tem afinidade cálcio-alcalina peraluminosa, enriquecimento em Ba e Sr, e padrões de ETR sem anomalias expressivas de Eu e acentuado fracionamento de ETRP. Suas altas razões La/ Yb sugerem ter sido derivado de magmas gerados em condições equivalentes ao campo de estabilidade da granada (1,0 a 1,5 GPa), como também sugerido para a Suíte Guarantã ( 2,87 Ga) do Domínio Rio Maria. Sua origem pode estar relacionada à fusão discreta de rochas TTG e/ou interação destas com fluidos enriquecidos em K, Sr e Ba, derivados do manto metassomatizado. Os leucogranitos revelam assinatura geoquímica de granitos tipo-A reduzidos, possivelmente originados a partir da fusão desidratada de rochas cálcio-alcalinas peraluminosas durante o Neoarqueano. Além dessas unidades, foi descrito na porção leste do Leucogranodiorito um hornblenda-biotita-granito afim geoquimicamente aos granitos tipo-A oxidados, correlacionado à Suíte Vila Jussara, também neoarquena. Este trabalho sugere que a porção estudada pode apresentar ligação evolutiva com o Domínio Rio Maria, tendo sido afetada por eventos de retrabalhamento crustal durante o Neoarqueano.
\end{abstract}

Palavras-chave: Leucogranodiorito Pantanal. Cálcio-alcalino. Leucogranitos tipo-A. Arqueano. Subdomínio de Transição. Província Carajás.

\begin{abstract}
In the eastern part of the Transition Subdomain, leucogranodiorites (Pantanal Leucogranodiorite), apparently crosscut TTG rocks (Colorado Trondhjemite; 2.87 Ga), and are crosscut by deformed leucogranites on its western portion. The peraluminous Pantanal Leucogranodiorite shows calc-alkaline affinities, with high contents of Ba and Sr. REE patterns are devoid of significant Eu anomalies and HREE are strongly fractionated. The high La/Yb ratios are similar to those of the Guarantã Suite $(\sim 2.87 \mathrm{Ga})$ from the Rio Maria Domain and suggest that the granodiorite magma was formed in the stability field of garnet (10-15 kbar). Its origin may be related to low degrees of melting of $T \mathrm{TG}$, probably accompanied by interaction with fluids enriched in $\mathrm{K}, \mathrm{Ba}$ and $\mathrm{Sr}$, derived from a metasomatized mantle. The leucogranites have A-type geochemical signature, reduced character, and may have originated from the melt of dehydrated peraluminous calc-alkaline rocks during the Neoarchean. In the eastern portion of the Pantanal Leucogranodiorite stock was identified an oxidized hornblende-biotite monzogranite, geochemically akin of A-type granites, that is correlated with the Neoarchean Vila Jussara Suite. The results suggest that the studied portion of the Transition Subdomain was affected by crustal reworking during the Neoarchean and could represent an extension of Rio Maria Domain.
\end{abstract}

Keywords: Pantanal Leucogranodiorite. Calc-alkaline. A-type Leucogranite. Archean. Transition Subdomain. Carajás Province.

TEIXEIRA, M. F. B., R. DALL'AGNOL, A. C. SILVA \& P. A. SANTOS, 2013. Geologia, petrografia e geoquímica do Leucogranodiorito Pantanal e dos leucogranitos arqueanos da área a norte de Sapucaia, Província Carajás, Pará: implicações petrogenéticas. Boletim do Museu Paraense Emílio Goeldi. Ciências Naturais 8(3): 291-323.

Autor para correspondência: Mayara Fraeda Barbosa Teixeira. Universidade Federal do Pará. Instituto de Geociências. Rua Augusto Corrêa, n. 1 - Guamá. Belém, PA, Brasil. Caixa Postal 8608. CEP 66075-900 (mayfraeda@gmail.com).

Recebido em 20/05/2013

Aprovado em 28/11/2013

Responsabilidade editorial: Fernando Jacques Althoff

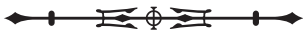




\section{INTRODUÇÃO}

Nos crátons arqueanos descritos em diversos locais do mundo, as associações tonalito-trondhjemito-granodiorito (TTG) constituem os granitoides dominantes (Kröner et al., 1991; Condie, 1993; Martin, 1994). Entretanto, uma diversidade de maciços leucogranodioríticos e graníticos apresenta distribuição areal importante e compõe cerca de 20\% daqueles terrenos (Cassidy et al., 1991; Sylvester, 1994; Davis et al., 1994). Tais leucogranodioritos e granitos formam corpos de dimensões variáveis, comumente intrusivos em outras variedades de granitoides (suítes TTG ou sanukitoides) ou em sequências supracrustais. Na Província Carajás (Figura 1A), diversos plútons e stocks representativos desse tipo de magmatismo têm sido identificados (Barros et al., 1997, 2009; Althoff et al., 2000; Leite et al., 2004; Sardinha et al., 2006; Vasquez et al., 2008; Almeida et al., 2010, 2013; Feio et al., 2012; Feio \& Dall'Agnol, 2012).

No Subdomínio de Transição, que representa a porção sul do Domínio Carajás da província homônima, mais especificamente na região compreendida entre as cidades de Sapucaia e Canaã dos Carajás (Figura 1B), foram reportadas expressivas ocorrências de granitoides arqueanos. O Subdomínio de Transição destaca-se dentro da província devido aos debates sobre sua evolução geológica e contexto geotectônico, haja vista que ainda há grandes lacunas, em particular sobre sua porção oriental, apesar dos avanços no conhecimento dessa região. O Subdomínio de Transição foi interpretado por Dall'Agnol et al. (2006) como sendo um terreno similar ao Domínio Rio Maria, sendo, porém, afetado pelos eventos neoarqueanos atuantes na Bacia Carajás. Contudo, estudos realizados por Feio et al. (2013) na região de Canaã dos Carajás, na porção norte do Subdomínio de Transição, sugeriram uma evolução distinta daquela área em relação ao Domínio Rio Maria.

O magmatismo granitoide arqueano exposto nas proximidades de Sapucaia envolve diversos granitos com assinaturas geoquímicas distintas. Entre estes, ocorrem leucogranodioritos de textura porfirítica, seccionados por leucogranitos deformados arqueanos com assinatura geoquímica similar à de granitos tipo-A. $\bigcirc$ objetivo deste trabalho é apresentar novos dados de campo, efetuar a caracterização petrográfica e geoquímica e uma interpretação preliminar quanto à petrogênese desses granitos e compará-los a granitoides similares, tanto da Província Carajás quanto de outros crátons arqueanos, a fim de contribuir para o avanço da compreensão da evolução magmática e, indiretamente, tectônica do Subdomínio de Transição.

\section{MATERIAIS E MÉTODOS}

O mapeamento geológico foi realizado na escala 1:50.000, no qual se aplicaram as técnicas clássicas de mapeamento, com levantamento de afloramentos e coleta sistemática de 34 amostras. Para apoio dos trabalhos de mapeamento, utilizaram-se imagens de satélite (Landsat 7 e TM - NASA, 2003), mosaicos de radar (Shuttle RADAR Topography Mission - SRTM - Universidade Maryland, 2009) e cartas aerorradiométricas. A localização dos pontos amostrados foi feita por meio do Global Position System (GPS).

A confecção de lâminas delgadas para o estudo petrográfico foi realizada na Oficina de Laminação do Instituto de Geociências da Universidade Federal do Pará (IG/UFPA). Foram confeccionadas 21 lâminas delgadas e obtidas 17 composições modais, com contador automático de pontos da marca Swift (1.800 pontos por lâmina delgada). A petrografia serviu de base para selecionar amostras para os estudos geoquímicos, e todas as amostras escolhidas para análises químicas foram previamente submetidas à análise modal, de modo a definir com mais rigor suas composições mineralógicas.

As amostras selecionadas para as análises químicas foram trituradas, pulverizadas, homogeneizadas e quarteadas, visando a obter uma boa representatividade do material. Essa etapa foi realizada na Oficina de Preparação de Amostras (OPA), pertencente ao Instituto de Geociências da UFPA. As análises químicas foram realizadas no laboratório comercial Acme Analytical Laboratories Ltd. (Vancouver, Canadá), por Inductively Coupled Plasma - Emission Spectrometry (ICP-ES), 

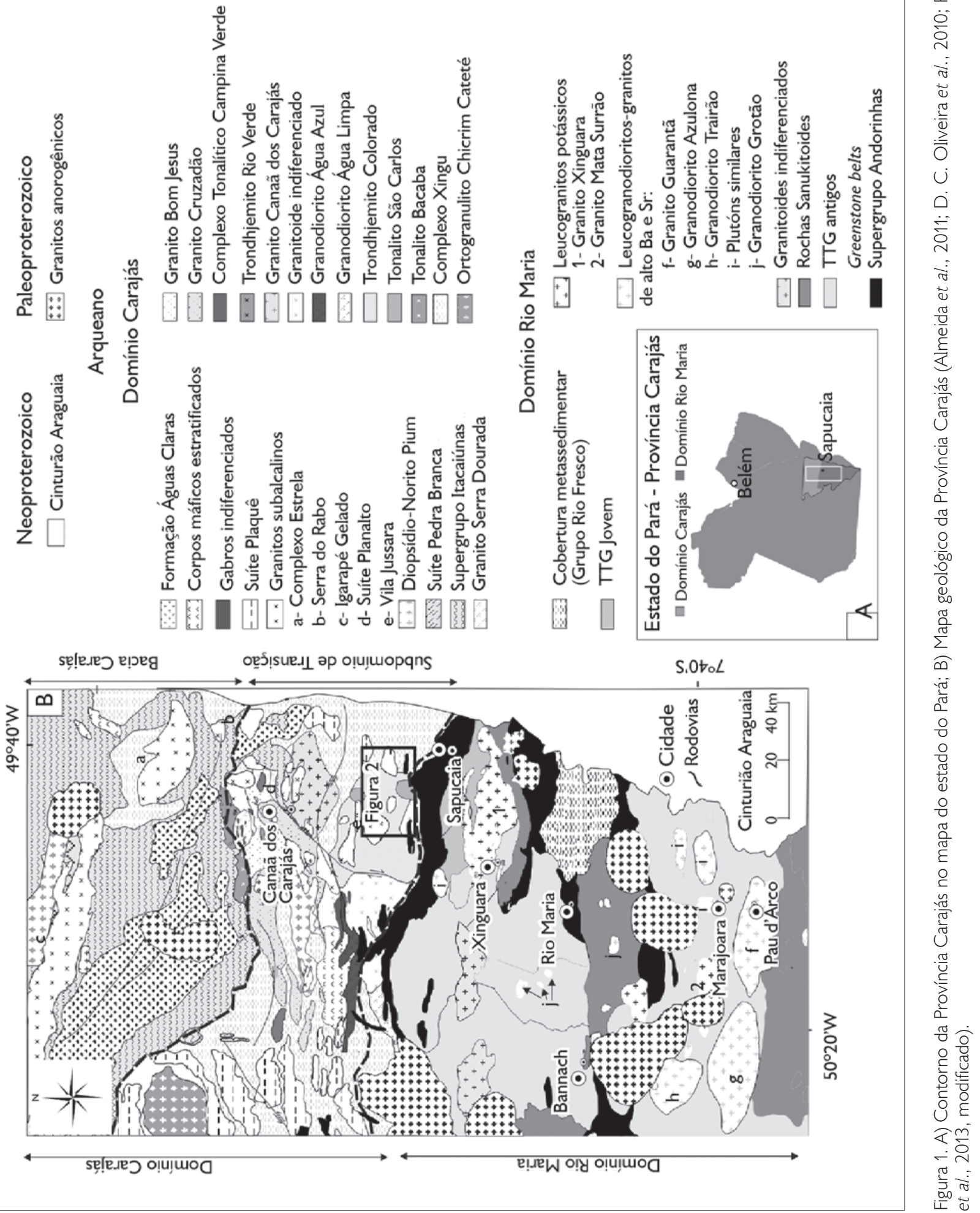
no caso de elementos maiores e menores $\left(\mathrm{SiO}_{2}, \mathrm{TiO}_{2}\right.$, $\mathrm{Al}_{2} \mathrm{O}_{3}, \mathrm{Fe}_{2} \mathrm{O}_{3 \mathrm{t}}, \mathrm{MgO}, \mathrm{CaO}, \mathrm{MnO}, \mathrm{Na}_{2} \mathrm{O}, \mathrm{K}_{2} \mathrm{O}, \mathrm{P}_{2} \mathrm{O}_{5}$ ), e por Inductively Coupled Plasma - Mass Spectrometry (ICP-MS), no caso dos elementos-traço (Rb, Sr, Ba, Ga, Y, Zr, Nb, U, Th, Cr, Ni e V), inclusive os ETR (La, Ce, Pr, Nd, Sm, Eu, Gd, Tb, Dy, Ho, Er, Tm, Yb e Lu).

Essas análises permitiram discriminar e classificar com maior precisão as unidades estudadas, assim como compará-las com outros granitoides. Os diagramas de Harker, para fins petrogenéticos, foram feitos através do software GCDKIT e a sua avaliação estatística efetivada com base no estudo da correlação entre os valores de $X$ e Y, por meio de respectivos coeficientes de correlação de Pearson (r), realizados no Microsoft Excel, na função Pearson (Microsoft, 2012).

\section{A PROVÍNCIA CARAJÁS E SEU MAGMATISMO GRANÍTICO ARQUEANO}

A Província Carajás constitui o principal núcleo arqueano do Cráton Amazônico e integra, segundo Tassinari \& Macambira (2004), a porção sudeste da Província Amazônia Central. Já Santos et al. $(2000,2006)$ consideram o bloco arqueano de Carajás como uma província independente. É limitada a oeste por terreno dominado por granitos e rochas vulcânicas paleoproterozoicas (Supergrupo Uatumã), a leste pelo Cinturão Araguaia, de idade neoproterozoica, a norte pela Província Maroni-Itacaiúnas e a sul pelo Domínio Santana do Araguaia, os dois últimos formados durante o evento Transamazônico (2,2-2,1 Ga). Essa Província é dividida (Althoff et al., 2000; Dall'Agnol et al., 2006; Vasquez et al., 2008) em dois domínios distintos (Figura 1B): o Domínio Rio Maria, a sul, formado por sequências metavulcano-sedimentares tipo greenstone belt, do Supergrupo Andorinhas, e granitoides arqueanos diversos; o Domínio Carajás, a norte, subdividido em Bacia Carajás e Subdomínio de Transição.

Nessa Província, diversos grupos de granitos arqueanos com idades entre 3,0 a 2,7 Ga têm sido identificados com base em características petrográficas e assinaturas geoquímicas. No Domínio Rio Maria, foram distinguidos três tipos de granitos arqueanos (Almeida et al., 2010, 2013): 1) leucogranodioritos-granitos ( 2,87) formados pelos plútons da Suíte Guarantã (Guarantã, Azulona, Trairão; Althoff et al., 2000; Almeida et al., 2010) e pelo Granodiorito Grotão (Guimarães et al., comunicação pessoal). São rochas fortemente deformadas, foliadas, de coloração rosada e textura porfirítica, com exceção do Granodiorito Grotão, que é equigranular e de granulação fina. Apresentam, em geral, razão $\mathrm{K}_{2} \mathrm{O} / \mathrm{Na}_{2} \mathrm{O}$ variando entre 0,5 e 1, altos conteúdos de Ba e Sr, padrões de ETR com fracionamento expressivo, porém variável de ETR pesados em relação aos leves, e, em geral, anomalias de Eu ausentes ou pouco marcantes (Almeida et al., 2010). Tais rochas foram interpretadas como produto de mistura em diferentes proporções de magmas de composição trondhjemítica do tipo TTG e leucogranítica rica em $\mathrm{Ba}$ e Sr, derivada de magmas sanukitoides (Almeida et al., 2010); 2) leucogranitos potássicos (2,87-2,86 Ga), representados principalmente pelos granitos Xinguara (Leite et al., 1999) e Mata Surrão (Duarte et al., 1991; Duarte \& Dall'Agnol, 1996), o primeiro formando plúton alongado segundo a direção E-W a WNW-ESE. Possuem altos conteúdos de $\mathrm{K}_{2} \mathrm{O}$, moderados de $\mathrm{Sr}$ e Ba, e padrões de ETR mostrando enriquecimento em ETR leves, forte ou moderado fracionamento dos ETR pesados e moderada a pronunciada anomalia negativa de Eu; 3) granitos associados a suítes sanukitoides (2,89 Ga; Almeida et al., 2013; M. A. Oliveira et al., 2009, 2010).

No Domínio Carajás, afloram diversos granitos mesoarqueanos com idades entre 2,95 e 2,85 Ga (Feio et al., 2013; Feio \& Dall'Agnol, 2012; Gomes \& Dall'Agnol, 2007). Esses granitos são, em geral, peraluminosos, mas apresentam expressivas variações geoquímicas, podendo ter afinidade cálcio-alcalina ou transicional para alcalina e exibir fracionamento dos ETR pesados e anomalias negativas de Eu bastante variados (Feio \& Dall'Agnol, 2012).

No Subdomínio de Transição (porção sul do Domínio Carajás), afloram anfibólio-granodioritos de alto Mg com 
idades de 2,88 e 2,87 Ga (Gabriel \& Oliveira, comunicação pessoal, 2013; Gabriel et al., 2010; Souza et al., 2010), similares aos granodioritos arqueanos ricos em $\mathrm{Mg}$ da Suíte Rio Maria (Gabriel \& Oliveira, comunicação pessoal, 2013). Na porção extremo leste desse Subdomínio, ocorrem rochas tonalíticas distintas das associações TTG clássicas, as quais foram denominadas de Tonalito São Carlos (2,94 Ga; Guimarães et al., 2012; Silva et al., comunicação pessoal, 2013), e clássicas suítes TTG arqueanas, denominadas Trondhjemito Colorado ( 2,87 Ga; Silva et al., 2010; Silva et al., comunicação pessoal, 2013).

O magmatismo granítico neoarqueano no Domínio Carajás é representado por granitos subalcalinos foliados ( 2,75 Ga): 1) Complexo Granítico Estrela (Barros \& Dall'Agnol, 1994; Barros et al., 1997) e Granito Serra do Rabo (Sardinha et al., 2006). São dominantemente monzogranitos a álcali feldspato-granitos, exibem altas razões Fe/Mg e altos conteúdos de HFSE, ou seja, apresentam assinatura geoquímica similar à dos granitos tipo-A (Barros et al., 2001, 2009); 2) Suíte Plaquê (Araújo et al., 1988; Araújo \& Maia, 1991), constituída por corpos de muscovita-biotita-leucogranitos foliados, com idades de 2,74-2,72 Ga. Possuem assinatura metaluminosa a peraluminosa, e foram interpretados como granitoides tipo-S (Araújo \& Maia, 1991); 3) Suíte Planalto (Huhn et al., 1999; Gomes \& Dall'Agnol, 2007; Vasquez et al., 2008; D. C. Oliveira et al., 2010; Feio et al., 2012, 2013), formada por diversos plútons de biotita-hornblendamonzogranitos a sienogranitos com álcali feldspatogranito associados, com idade entre 2,74 Ga e 2,73 $\mathrm{Ga}$. Exibem altas razões $\mathrm{K}_{2} \mathrm{O} / \mathrm{Na}_{2} \mathrm{O}$ e $\mathrm{FeO} /\left(\mathrm{FeO}_{\mathrm{t}}+\right.$ $\mathrm{MgO}$ ), altos conteúdos de $\mathrm{Zr}$, Y, Nb e ETRP e mostram afinidades com granitos tipo-A reduzidos; 4) Granitos Vila Jussara, recentemente descritos (Silva et al., comunicação pessoal, 2013), compostos por granitos, granodioritos e tonalitos, alongados segundo a direção E-W, com idades entre 2,75 e 2,72 Ga (Guimarães et al., 2012). São metaluminosos, possuem baixo fracionamento de ETR pesados em relação aos leves e apresentam anomalias negativas de Eu significativas (Silva et al., comunicação pessoal, 2013).

\section{GEOLOGIA DA ÁREA DE ESTUDO}

$\mathrm{Na}$ área de estudo, situada a norte e noroeste da cidade de Sapucaia, foram identificadas rochas de composição leucogranodiorítica com textura porfirítica, denominadas neste trabalho de Leucogranodiorito Pantanal, em virtude de o principal stock da unidade ser drenado pelo córrego Pantanal (Figura 2).

Esse leucogranodiorito forma um corpo de aproximadamente $40 \mathrm{~km}^{2}$, que configura uma pequena serra (Figura 3A), alongada segundo a direção E-W, localizada a noroeste de Sapucaia. Define colinas suaves, cobertas por vegetação fechada, destacando-se na paisagem do terreno. Essa geomorfologia é contrastante com a da associação tonalito-trondhjemito-granodiorito (Trondhjemito Colorado; Santos et al., 2013), que predomina na área.

O Leucogranodiorito Pantanal é composto por rochas de cor cinza esbranquiçada a rosada, de textura porfirítica, caracterizadas por apresentarem fenocristais de granulação média a grossa de feldspato potássico em matriz fina (Figura 3B). Mostram-se fortemente foliadas nas porções mais externas do corpo, próximo a zonas de cisalhamento, onde exibem porfiroclastos ovalados de feldspato potássico e foliações tendendo a E-W. Mais distante dessas zonas, possuem foliação incipiente ou, por vezes, aspecto homogêneo. Não foram observados enclaves nessas rochas. Há evidências de que esta unidade foi afetada por zonas de cisalhamento E-W, que possivelmente moldaram a atual forma alongada do corpo.

$\mathrm{Na}$ porção oeste da serra, ocorrem leucogranitos do tipo-A (ver adiante) deformados, que seccionam o Leucogranodiorito Pantanal (Figuras 3C-3D), indicando relação de intrusão. Também foram identificadas ocorrências do leucogranito e de granitoides distintos na porção centro-leste do stock granodiorítico, nas encostas de vale de difícil acesso (Figura 3E). Não foram 


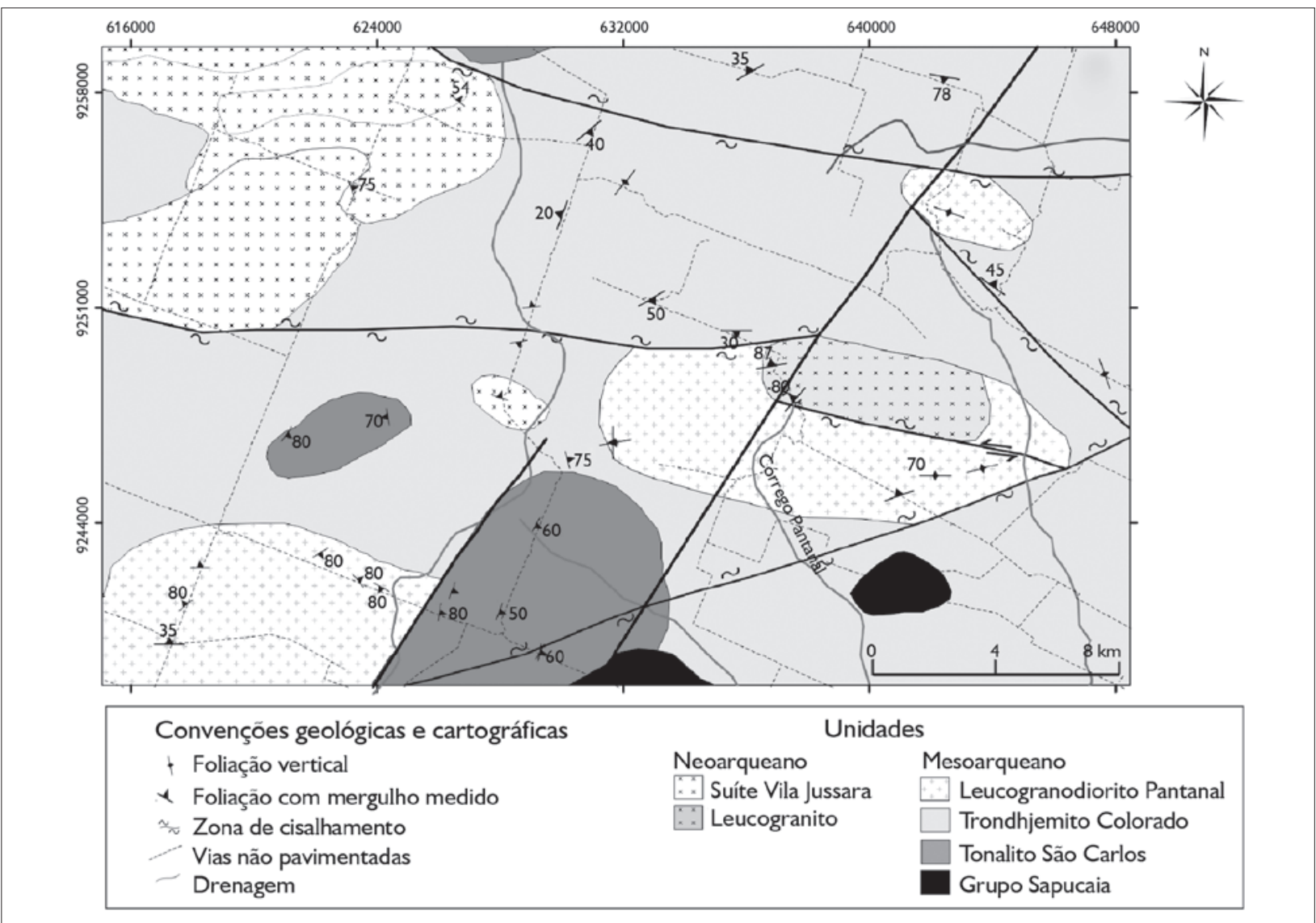

Figura 2. Mapa geológico da área a N e NW de Sapucaia, na porção leste do Subdomínio de Transição (Silva et al., comunicação pessoal, 2013; este trabalho).

observadas relações de contato entre esses granitoides e o granodiorito, tampouco foi possível definir a extensão da sua área aflorante. Tais granitoides mostraram afinidades geoquímicas com granitos tipo-A e similaridade com aqueles da Suíte Vila Jussara (ver adiante).

A morfologia do Leucogranodiorito Pantanal e dos granitos associados destaca-se em imagem SRTM (Figura $4 A$ ), em imagem de aerogamaespectrometria (canal do Th; Figura 4B) e na imagem de fusão destas (Figura 4C). Os stocks graníticos exibem comportamento altamente radiométrico e definem anomalia positiva que contrasta com o padrão fracamente radiométrico mostrado pelo Trondhjemito Colorado. Não foram observadas relações de contato entre o granodiorito e suas encaixantes.
Entretanto, a amostragem sistemática realizada permite, em geral, uma delimitação adequada dos domínios dos diferentes granitoides.

Além da área-tipo, esse leucogranodiorito foi identificado na porção da área mapeada, formando stock de menor expressão. Os dois stocks de granodiorito e suas encaixantes são cortados por um lineamento estrutural de direção NE-SW, de grande expressão na área, representado em campo por zonas de intensa silicificação, nas quais foi observada a presença de veios de quartzo englobando fragmentos alterados de granodiorito.

A oeste do principal stock de granodiorito, no sudoeste da área mapeada, Silva et al. (comunicação pessoal, 2013) identificaram um stock de rochas granodioríticas similares






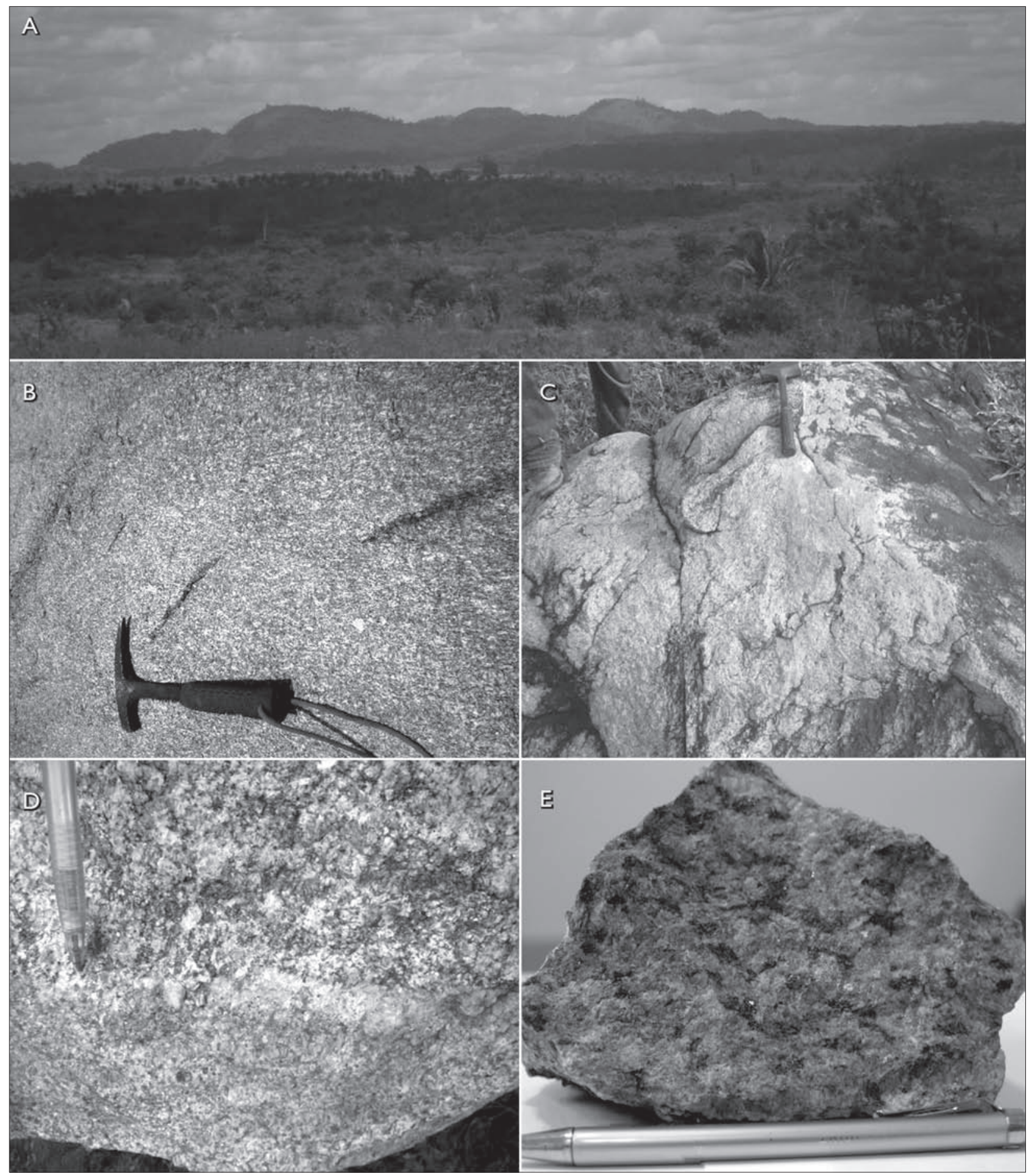

Figura 3. Aspectos de campo das unidades estudadas (A, B, C, D): A) fotografia mostrando a morfologia da serra que constitui o principal corpo do Leucogranodiorito Pantanal; B) textura porfirítica, característica do Leucogranodiorito Pantanal; C) e D) relações de contato entre o Leucogranodiorito Pantanal (cinza rosado) e o leucogranito tipo-A (róseo), com o último seccionando o primeiro; E) fotografia mostrando o aspecto de amostra de mão do granito associado à Suíte Vila Jussara. Fotos: M. F. B. Teixeira. 
A



B

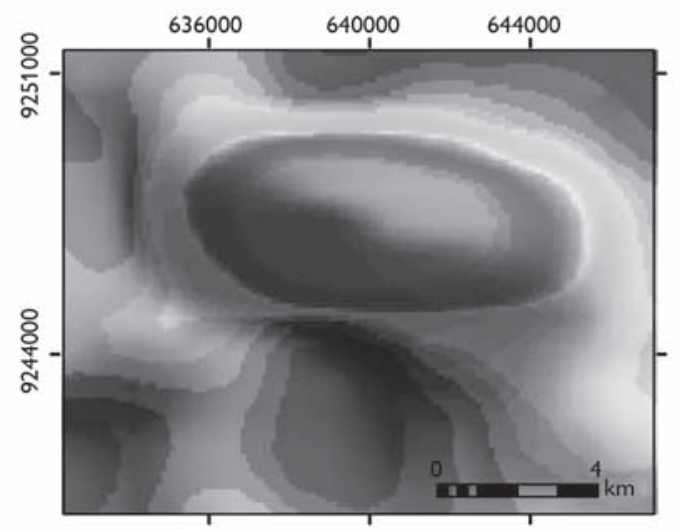

644000
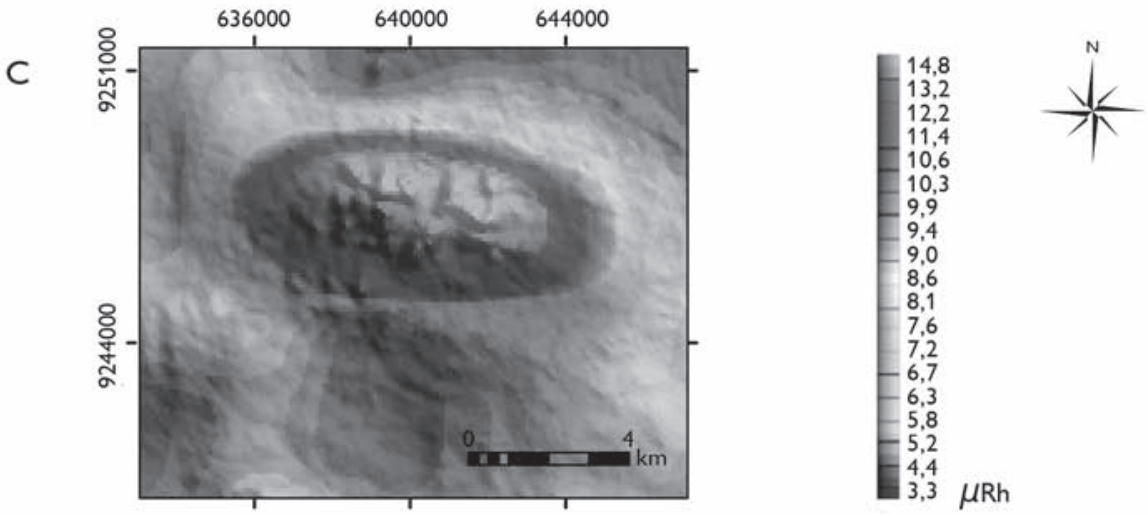

$\mu \mathrm{Rh}$

Figura 4. A) Imagem de radar, mostrando uma visão geral de stock do Leucogranodiorito Pantanal e granitos associados, que se distingue de suas encaixantes pelo relevo mais expressivo; B) imagem aerogamaespectométrica (canal do Th) mostrando a anomalia positiva relacionada com os granitoides que configuram a serra; C) imagem de fusão de aerogamaespectrometria (canal do Th) e Shuttle Radar Topography Mission (SRTM).

ao Leucogranodiorito Pantanal (Figura 2), que ocorrem em uma planície, com relativa carência de exposições, configurando um relevo arrasado destoante daquele da serra. As rochas aí expostas exibem foliações penetrativas predominantemente E-W, com mergulhos de alto ângulo, ou, localmente, N-S, no contato com o Tonalito São Carlos (Silva et al., comunicação pessoal, 2013). Não apresentam enclaves e constata-se abundância de veios leucograníticos seccionando essa unidade.

Os leucogranitos que seccionam o Leucogranodiorito Pantanal na porção oeste da serra são intensamente deformados, possuem granulação média a fina, cor rosada a avermelhada, e ocorrem como veios e bolsões métricos. Há, porém, evidências de que possam existir exposições de maior volume em morros que não puderam ser amostrados. Tal hipótese deve ser verificada em futuros estudos.

\section{PETROGRAFIA}

\section{COMPOSIÇÕES MODAIS E CLASSIFICAÇÃO}

Foram realizadas dez análises modais de amostras do Leucogranodiorito Pantanal, cinco de leucogranito e duas amostras de hornblenda-biotita-granito (Tabela 1). Os resultados foram lançados em diagramas Q-A-P

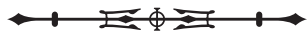


Tabela 1. Composições modais de amostras do Leucogranodiorito Pantanal, leucogranito e hornblenda-biotita-granito (Hb-Bt-granito). Legendas: * = amostra com análise química; $(\mathrm{s})$ = mineral secundário; $(\mathrm{p})$ = mineral primário; - = mineral não observado na amostra; $\mathrm{Tr}=$ mineral presente na rocha, mas não significativo na contagem modal.

\begin{tabular}{|c|c|c|c|c|c|c|c|c|c|c|c|c|c|c|c|c|c|c|c|}
\hline \multirow{2}{*}{ 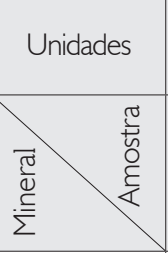 } & \multicolumn{12}{|c|}{ Leucogranodiorito Pantanal } & \multicolumn{5}{|c|}{ Leucogranito } & \multicolumn{2}{|c|}{$\begin{array}{l}\mathrm{Hb}-\mathrm{Bt}- \\
\text { granito }\end{array}$} \\
\hline & 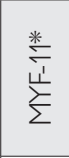 & $\underset{⿱ 亠 䒑}{\stackrel{*}{+}}$ &  & 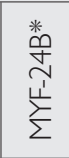 &  & $\begin{array}{l}\stackrel{*}{\stackrel{*}{*}} \\
\stackrel{\mu^{\prime}}{\Sigma} \\
\Sigma\end{array}$ & $\underset{\substack{\stackrel{m}{\mu^{\prime}} \\
\sum}}{\sum}$ &  & $\stackrel{\substack{\stackrel{n}{\mu^{\prime}} \\
\sum}}{\Sigma}$ & 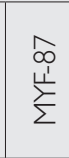 & 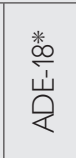 & 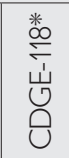 & 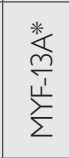 & $\underset{\sum}{\stackrel{*}{\stackrel{*}{\rightleftharpoons}}}$ & 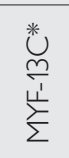 & 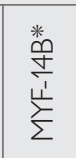 & 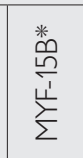 & 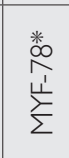 & 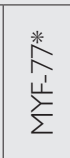 \\
\hline Plagioclásio & 55,9 & 49,9 & 49,8 & 53,1 & 51,1 & 52,2 & 47,6 & 48,8 & 49,2 & 57,4 & 51,6 & 43,8 & 42,2 & 43,6 & 40,4 & 42,4 & 45,9 & 24 & 35,1 \\
\hline Quartzo & 24 & 27,5 & 28,8 & 27,5 & 29 & 27 & 29,8 & 25,6 & 22 & 24,8 & 30,3 & 36,6 & 20,5 & 22,3 & 24,9 & 24,3 & 23,3 & 25 & 17,9 \\
\hline $\begin{array}{l}\text { Feldspato } \\
\text { potássico }\end{array}$ & 15,2 & 18,8 & 16,7 & 15,9 & 12,8 & 13 & 15,6 & 14,1 & 23 & 11,5 & 11 & 10,5 & 34,4 & 31,8 & 32,6 & 29,6 & 29,1 & 40,8 & 32,6 \\
\hline Biotita & 3,5 & 3,3 & 3,2 & 3 & 3,9 & 6,2 & 5 & 8,2 & 3,2 & 5,1 & 6,2 & 8,1 & - & 0,6 & 0,6 & 2,2 & 0,2 & 8,8 & 8,3 \\
\hline Hornblenda & - & - & - & - & - & - & - & - & - & - & - & - & - & - & - & - & - & - & 3,6 \\
\hline Muscovita (p) & 0,4 & 0,6 & 0,5 & - & 2,5 & 1,1 & 1,4 & 2,2 & 1,6 & 0,7 & 0,1 & 0,6 & 2,4 & 1 & 0,9 & 0,9 & 1 & 0,4 & - \\
\hline Epidoto (p) & $\operatorname{Tr}$ & 0,1 & $\operatorname{Tr}$ & 0,1 & 0,2 & $\operatorname{Tr}$ & 0,2 & 0,4 & 0,3 & 0,3 & Tr & $\operatorname{Tr}$ & - & - & - & - & - & - & 0,5 \\
\hline Allanita & 0,2 & $\operatorname{Tr}$ & 0,3 & 0,1 & $\operatorname{Tr}$ & 0,1 & 0,1 & 0,2 & $\operatorname{Tr}$ & $\mathrm{Tr}$ & 0,1 & $\operatorname{Tr}$ & $\operatorname{Tr}$ & - & 0,3 & 0,5 & Tr & 0,4 & $\operatorname{Tr}$ \\
\hline Opacos & 0,4 & 0,2 & 0,4 & 0,2 & 0,1 & $\operatorname{Tr}$ & Tr & 0,1 & 0,1 & 0,2 & 0,3 & $\operatorname{Tr}$ & 0,2 & 0,2 & - & 0,4 & $\operatorname{Tr}$ & $\operatorname{Tr}$ & 0,4 \\
\hline Titanita & - & - & $\operatorname{Tr}$ & - & - & - & - & 0,1 & 0,3 & - & Tr & Tr & - & - & - & - & Tr & - & 1 \\
\hline Apatita & 0,1 & 0,1 & Tr & $\operatorname{Tr}$ & Tr & $\operatorname{Tr}$ & Tr & 0,1 & 0,2 & $\mathrm{Tr}$ & Tr & $\operatorname{Tr}$ & $\operatorname{Tr}$ & - & - & Tr & Tr & Tr & $\operatorname{Tr}$ \\
\hline Zircão & Tr & 0,1 & Tr & 0,1 & 0,2 & $\operatorname{Tr}$ & $\operatorname{Tr}$ & $T r$ & $\operatorname{Tr}$ & $\mathrm{Tr}$ & $T r$ & Tr & Tr & 0,1 & - & Tr & 0,1 & 0,3 & 0,2 \\
\hline Epidoto (s) & $\operatorname{Tr}$ & $\operatorname{Tr}$ & $\mathrm{Tr}$ & $\operatorname{Tr}$ & $\operatorname{Tr}$ & Tr & Tr & $\operatorname{Tr}$ & Tr & $\mathrm{Tr}$ & Tr & $\operatorname{Tr}$ & - & - & - & Tr & Tr & $\operatorname{Tr}$ & $\operatorname{Tr}$ \\
\hline Fluorita & - & - & - & - & - & - & - & - & - & - & - & - & - & Tr & $\operatorname{Tr}$ & - & - & - & - \\
\hline$A+P$ & 71,1 & 68,7 & 66,5 & 69 & 63,9 & 65,2 & 63,2 & 62,9 & 72,2 & 68,9 & 62,6 & 54,3 & 76,6 & 72,4 & 73 & 68 & 72 & 64,8 & 67,7 \\
\hline Máficos & 4,1 & 3,6 & 3,9 & 3,4 & 4,2 & 6,3 & 5,3 & 9 & 3,9 & 5,6 & 6,6 & 8,1 & 0,8 & 0,8 & 0,9 & 3,1 & 1 & 9,5 & 13,3 \\
\hline
\end{tabular}

(Streckeisen, 1976) e Q-A+P-M' (Figura 5), nos quais os leucogranodioritos situam-se exclusivamente no campo dos granodioritos, enquanto o leucogranito e o hornblendabiotita-granito plotam no campo dos monzogranitos. Em termos dos constituintes essenciais, essas rochas diferem entre si essencialmente pelas proporções de feldspatos.

As amostras analisadas do Leucogranodiorito Pantanal e do leucogranito possuem conteúdo de minerais máficos inferior a 10\%, sendo que os valores de M' variam de 3,4 a 9,0\% no Leucogranodiorito Pantanal e de 0,8 a 3,1\% nos leucogranitos (Tabela 1). O hornblenda-biotita-granito distingue-se dos demais pela presença eventual de anfibólio e proporção relativamente elevada de máficos (9,5 a
13,3\%; Tabela 1). Os leucogranitos são hololeucocráticos (M' < 5\%; Le Maitre, 2002), enquanto apenas 50\% das amostras de leucogranodioritos possuem tal característica e o hornblenda-biotita-granito é leucocrático. Em relação aos minerais félsicos essenciais, as percentagens de plagioclásio no Leucogranodiorito Pantanal variam de 51 a $57,4 \%$, as de quartzo de 22 a 29,8\% e as de feldspato potássico de 11,5 a 16,7\%; nos leucogranitos, o plagioclásio varia de 40,4 a $50,9 \%$, o quartzo de 20,5 a $28,3 \%$ e o feldspato potássico de 21,1 a 32,6\%. O principal mineral máfico nessas variedades é a biotita. $\bigcirc$ epidoto magmático é comum no Leucogranodiorito Pantanal, mas não ocorre no leucogranito. As fases minerais acessórias são muscovita, 


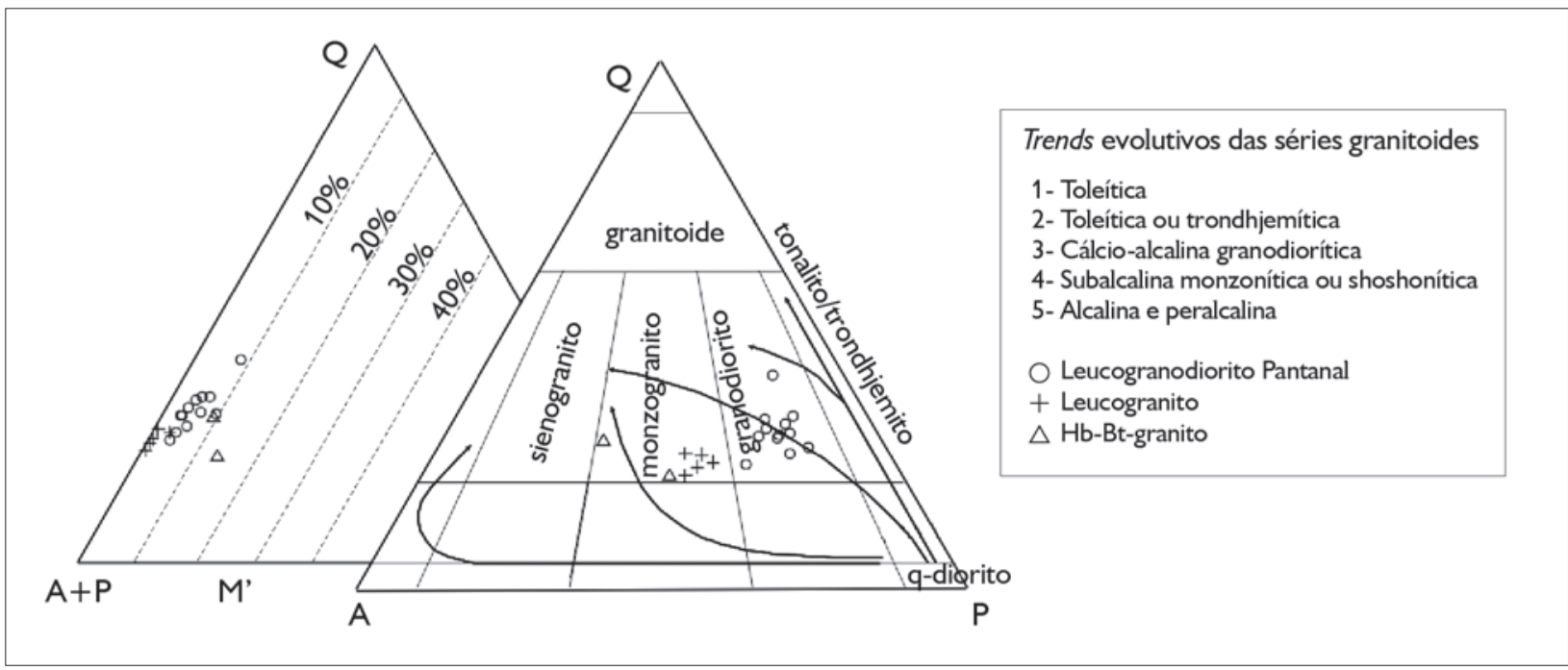

Figura 5. Diagramas Q-A-P e Q-A+P-M' (Streckeisen, 1976) do Leucogranodiorito Pantanal e granitos associados. Trends das séries granitoides conforme Bowden et al. (1984).

que no caso dos leucogranitos apresenta em geral proporções modais mais elevadas que a biotita, allanita, apatita, zircão e minerais opacos. Nos leucogranitos, há ainda a presença de fluorita. A titanita encontra-se ausente ou é pouco abundante nas amostras do Leucogranodiorito Pantanal e no leucogranito, aparecendo como acessório expressivo na amostra contendo anfibólio do hornblendabiotita-granito (Tabela 1).

\section{ASPECTOS TEXTURAIS DO LEUCOGRANODIORITO PANTANAL}

De modo geral, o Leucogranodiorito Pantanal é formado por rochas porfiríticas, caracterizadas por apresentarem fenocristais/porfiroclastos de plagioclásio e de feldspato potássico ovalados, grossos a médios, com bordas recristalizadas, em uma matriz de granulação fina a média, por vezes com textura granoblástica poligonal, marcada principalmente por cristais de quartzo e plagioclásio. Localmente é possível observar a orientação e estiramento dos cristais de quartzo (Figura 6A). A textura granular magmática foi obliterada pela deformação, no entanto, esporadicamente, observamse cristais subautomórficos.
O plagioclásio ocorre de duas formas: como fenocristais de granulação variando de média a grossa, e cristais xenomórficos de granulação fina. Os fenocristais mostram contornos irregulares e bordas parcialmente recristalizadas (Figura 6B). Apresentam inclusões de minerais opacos, biotita e muscovita. Alteram-se principalmente para argilominerais e subordinadamente para sericita e epidoto. Na segunda forma, apresentam contornos regulares e contatos retos a poligonais entre si e com cristais de quartzo, provenientes de recristalização. Podem ou não exibir maclas e apresentam extinção ondulante.

O quartzo exibe cristais xenomórficos de granulação média, os quais se acham deformados, possuem extinção ondulante e formam subgrãos. Localmente, apresentam-se orientados. Exibem contatos irregulares e, por vezes, estão inclusos em cristais de plagioclásio. Possuem forte extinção ondulante, foram recristalizados e ocorrem nos interstícios dos cristais e contornando fenocristais/porfiroclastos de plagioclásio e microclina pertítica. Ocorrem ainda formando agregados granoblásticos de cristais de granulação fina, com contornos regulares e contatos retos a poligonais entre si. Em menores proporções, ocorrem também

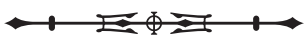


em intercrescimentos mirmequíticos, com plagioclásio, desenvolvidos ao longo das bordas de cristais de feldspato potássico de granulação média ou grossa.

feldspato potássico é uma microclina, que pode ser pertítica, apresentando lamelas sódicas em forma de cordões (Smith, 1974). Ocorre na matriz, com granulação fina a média, por vezes com maclas. Forma, ainda, fenocristais com granulação grossa (Figura 6C), bordejados por cristais de quartzo recristalizados e por cristais finos de biotita orientada. Apresentam localmente textura poiquilítica, marcada por inclusões de cristais subautomórficos de plagioclásio e biotita.
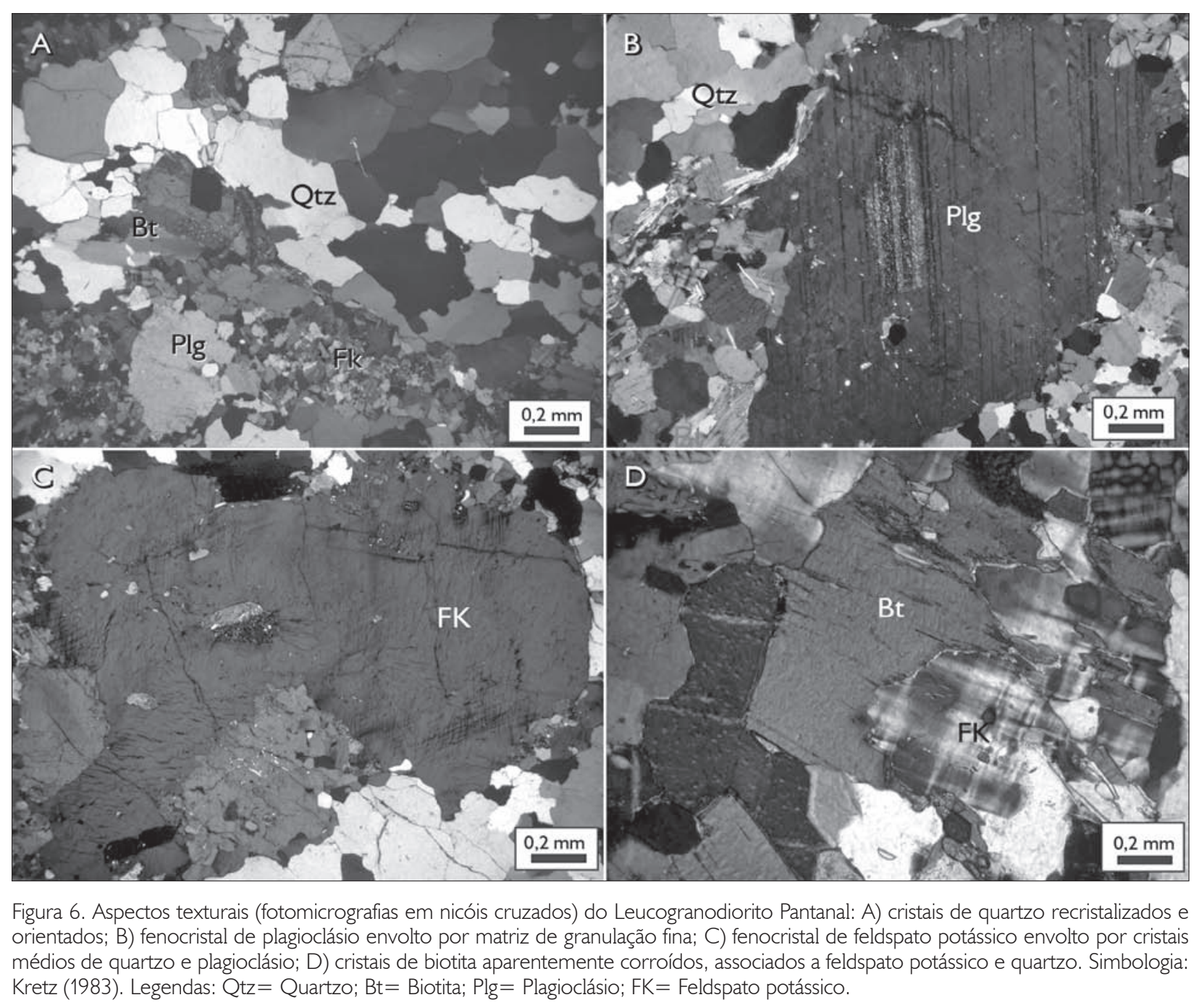

Figura 6. Aspectos texturais (fotomicrografias em nicóis cruzados) do Leucogranodiorito Pantanal: A) cristais de quartzo recristalizados e orientados; B) fenocristal de plagioclásio envolto por matriz de granulação fina; C) fenocristal de feldspato potássico envolto por cristais médios de quartzo e plagioclásio; D) cristais de biotita aparentemente corroídos, associados a feldspato potássico e quartzo. Simbologia: Kretz (1983). Legendas: Qtz= Quartzo; Bt= Biotita; Plg= Plagioclásio; FK= Feldspato potássico.
A biotita forma cristais subautomórficos de granulação fina a média, em geral orientados e marcando a foliação da rocha. Por vezes, associa-se a agregados de minerais máficos (epidoto, allanita, apatita, minerais opacos, titanita) e apresenta-se, ainda, inclusa no plagioclásio e no feldspato potássico ou associada a este (Figura 6D). Localmente, apresenta alteração para clorita.

A muscovita exibe lamelas de granulação fina a média. Ocorre geralmente associada à biotita. Possui contato reto ou subordinadamente irregular com a biotita.

$\bigcirc$ epidoto é encontrado em duas variedades texturais distintas: o epidoto I ocorre como cristais

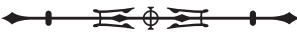


euédricos a subédricos, com faces bem definidas, comumente associados à biotita, sendo interpretados como de origem magmática; o epidoto II forma cristais anédricos muito finos, formando-se como produto de alteração de plagioclásio.

Em relação às fases acessórias, a allanita exibe cristais subédricos, finos, por vezes zonados; os minerais opacos mostram cristais finos, subédricos ou anédricos, os quais podem apresentar coroas de titanita; a titanita forma cristais de granulação fina, geralmente associada à biotita, ou como inclusões na mesma. Apatita e zircão formam cristais muito finos, inclusos em plagioclásio e biotita.

\section{ASPECTOS TEXTURAIS DOS LEUCOGRANITOS}

Os leucogranitos exibem fenocristais subédricos de feldspato potássico e, subordinadamente, plagioclásio, em matriz de granulação fina. São intensamente deformados e recristalizados, sendo esses efeitos mais proeminentes nos cristais de quartzo, os quais exibem subgrãos e neogrãos e, por vezes, mostram-se estirados e com forte extinção ondulante. Localmente, é possível observar a orientação da rocha definida principalmente por lamelas de micas (Figuras 7A-7B). São compostas essencialmente por feldspato potássico, plagioclásio e quartzo. Com exceção da amostra MYF-14B, a muscovita possui nesse granito conteúdo modal mais elevado do que a
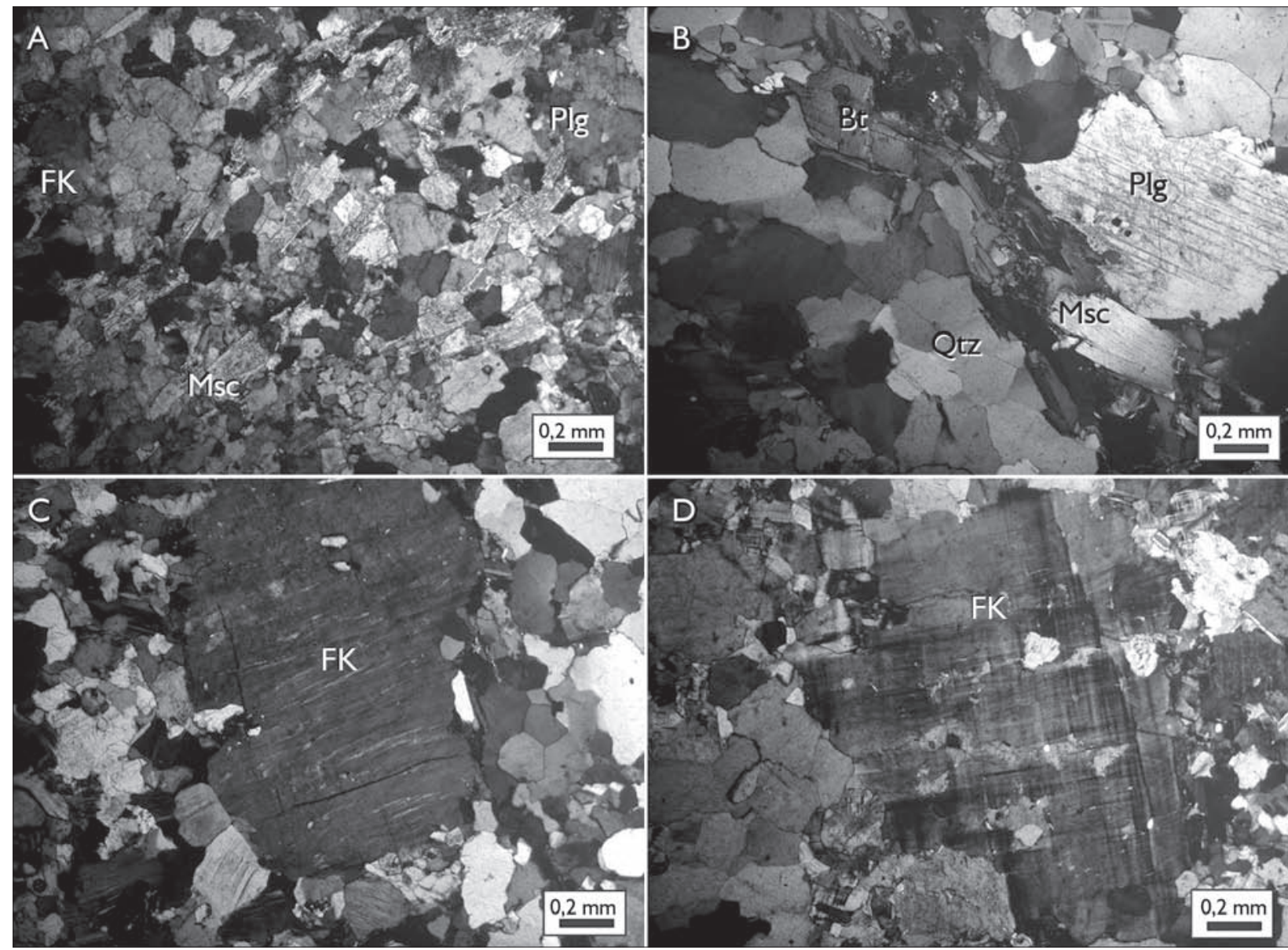

Figura 7. Aspectos texturais (fotomicrografias em nicóis cruzados) dos leucogranitos. A e B) Aspectos texturais, mostrando cristais de muscovita (A) e biotita (B), seguindo a orientação preferencial da rocha; C) fenocristal de feldspato potássico pertítico envolto por cristais finos de quartzo e feldspato recristalizado; D) fenocristal de microclina com inclusões de plagioclásio. Simbologia: Kretz (1983). Legendas: $\mathrm{Plg}=$ Plagioclásio; FK= Feldspato potássico; Msc= Muscovita; Bt= Biotita; Qtz= Quartzo.

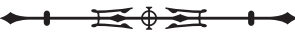


biotita, diferentemente do que ocorre no Leucogranodiorito Pantanal. Os minerais acessórios presentes são allanita, opacos, apatita e zircão, que possuem cristais de fluorita de granulação muito fina associados. Também se distinguem do leucogranodiorito por não possuírem epidoto primário e apresentarem apenas epidoto secundário, originado da alteração do plagioclásio. Tal como no leucogranodiorito, a titanita está ausente ou é inexpressiva nas amostras analisadas.

Os cristais de feldspato potássico são do tipo microclina e microclina pertítica (Figuras 7C-7D) e ocorrem tanto formando porfiroclastos $\left(\mathrm{FK}_{1}\right)$ quanto na matriz $\left(\mathrm{FK}_{2}\right) . \mathrm{O}$ $\mathrm{FK}_{1}$ ocorre bordejado por cristais recristalizados de feldspatos e quartzo. $\bigcirc \mathrm{FK}_{2}$ exibe cristais de granulação fina, pouco alterados e, por vezes, com maclas deformadas. A forma original dos cristaisfoi obliterada devido à deformação da rocha.

\section{ASPECTOS TEXTURAIS DO HORNBLENDA- BIOTITA-GRANITO}

Esse granito possui granulação variando de média a grossa e exibe textura granular a granoblástica (Figura 8A) ou, localmente, porfirítica, caracterizada pela presença de fenocristais de microclina (Figura 8B) e, subordinadamente, de plagioclásio subédrico. Apresenta-se intensamente deformado e recristalizado. A foliação é marcada principalmente por cristais de biotita e hornblenda, os quais se alternam com os minerais félsicos, formando um incipiente microbandamento composicional. Como principais fases minerais máficas, ocorrem biotita, hornblenda, epidoto e titanita, que, por vezes, podem formar agregados máficos (Figura 8C). Epidoto e titanita formam cristais de granulação fina, subédricos a euédricos (Figura 8D). Ocorrem ainda zircão, minerais opacos, apatita e allanita. A rocha encontrase moderadamente alterada, com cristais de plagioclásio saussuritizados e lamelas de biotita parcialmente substituídas por clorita, o que não se observa nos demais granitos.

\section{GEOQUÍMICA}

Inicialmente será realizada uma descrição das principais características das rochas estudadas, como o comportamento dos elementos maiores e traço (incluindo os ETR) e, por fim, a caracterização de suas séries magmáticas. As análises químicas dos granitoides estudados são fornecidas na Tabela 2. As duas amostras de hornblenda-biotita-granito analisadas (MYF-77 e MYF-78) acham-se representadas nos diagramas de Harker para os elementos maiores e traço (Figuras 9 e 10) e no diagrama de ETR (Figura 11). No entanto, devido ao número reduzido de amostras analisadas e por ser alvo de trabalho de outros pesquisadores, os dados serão apresentados e discutidos neste trabalho de modo sucinto, sobretudo com o objetivo de se estabelecer uma comparação preliminar desse granito com o Leucogranodiorito Pantanal e com o leucogranito.

\section{ELEMENTOS MAIORES E TRAÇO}

As rochas que compõem o Leucogranodiorito Pantanal e os leucogranitos apresentam conteúdo de $\mathrm{SiO}_{2}$ em intervalo restrito, respectivamente entre 72,8-73,62\% e 75,34$77,97 \%$, sendo os leucogranitos mais enriquecidos em sílica e não havendo superposição entre essas variedades (Tabela 2). O hornblenda-biotita-granito é mais pobre em $\mathrm{SiO}_{2}(69,7$ a $72 \%)$ do que as demais unidades.

Os diagramas de Harker (Figura 9) mostram que, no Leucogranodiorito Pantanal, os conteúdos de $\mathrm{TiO}_{2}$, $\mathrm{Al}_{2} \mathrm{O}_{3}, \mathrm{FeO}_{\mathrm{t}^{\prime}} \mathrm{CaO}$ e $\mathrm{Na}_{2} \mathrm{O}$ diminuem com o aumento de $\mathrm{SiO}_{2}$, enquanto que os valores de $\mathrm{K}_{2} \mathrm{O}$ e da razão $\mathrm{K}_{2} \mathrm{O} /$ $\mathrm{Na}_{2} \mathrm{O}$ aumentam. Segundo os coeficientes de correlação de Pearson, a correlação é fortemente negativa para $\mathrm{Al}_{2} \mathrm{O}_{3}$ e $\mathrm{Na}_{2} \mathrm{O}$, moderadamente negativa para $\mathrm{TiO}_{2}$ e $\mathrm{CaO}$, fracamente negativa para $\mathrm{FeO}_{\mathrm{t}}$, e fortemente positiva para $\mathrm{K}_{2} \mathrm{O}$ e para $\mathrm{K}_{2} \mathrm{O} / \mathrm{Na}_{2} \mathrm{O}$. Para os leucogranitos, a maioria dos óxidos exibe pouca variação, mas se constata correlação fortemente negativa nos casos de $\mathrm{Al}_{2} \mathrm{O}_{3}$ e $\mathrm{K}_{2} \mathrm{O}$ e moderadamente negativa para $\mathrm{TiO}_{2}$ e $\mathrm{CaO}$. Tanto no Leucogranodiorito Pantanal quanto nos leucogranitos, os teores de $\mathrm{MgO}$ não exibem variações significativas e, portanto, não definem um trend de correlação. Os teores de $\mathrm{Al}_{2} \mathrm{O}_{3}$ são altos no Leucogranodiorito Pantanal (14,51 a $15,52 \%)$, muito baixos nos leucogranitos (11,66 a 12,84\%) 



Figura 8. Aspectos texturais (fotomicrografias em nicóis cruzados) do hornblenda-biotita granito. A) Cristais de quartzo com textura em mosaico, associados com anfibólio; B) fenocristal de feldspato potássico bordejado por matriz fina, com destaque para lamelas finas de biotita; C); cristais de hornblenda, biotita e titanita formando agregados máficos; D) cristal euédrico de epidoto (Ep) associado com biotita (Bt) e titanita. Simbologia: Kretz (1983). Legendas: FK= Feldspato potássico; Hb= Hornblenda; Tit= Titanita; Ep= Cristal euédrico de Epidoto; $\mathrm{Bt}=\mathrm{Biotita.}$

e intermediários no hornblenda-biotita-granito $(13,08$ a 13,64\%). A somatória dos elementos ferromagnesianos é baixa no Leucogranodiorito Pantanal e nos leucogranitos (Tabela 2), no entanto é mais elevada no Leucogranodiorito Pantanal $\left(\mathrm{Fe}_{2} \mathrm{O}_{3}+\mathrm{MgO}+\mathrm{TiO}_{2}+\mathrm{MnO}=1,9 \mathrm{a} 2,67\right) \mathrm{em}$ comparação aos leucogranitos (1,05 a 1,67). O hornblendabiotita-granito possui caráter acentuadamente mais máfico, com a somatória dos elementos ferromagnesianos bem mais elevada $\left(\mathrm{Fe}_{2} \mathrm{O}_{3}+\mathrm{MgO}+\mathrm{TiO}_{2}+\mathrm{MnO}=4,79\right.$ a 5,75).

Os valores de \#Mg (Tabela 2) são moderados no Leucogranodiorito Pantanal $(0,29$ a 0,35), extremamente baixos nos leucogranitos $(0,02$ a 0,05$)$ e moderados no hornblenda-biotita-granito $(0,16$ a 0,26$)$. As razões $\mathrm{FeO}_{\mathrm{t}} /$
$\left(\mathrm{FeO}_{\mathrm{t}}+\mathrm{MgO}\right)$ distinguem muito bem essas variedades, sendo baixas no Leucogranodiorito Pantanal $(0,77$ a $0,81)$, moderadas a altas no hornblenda-biotita-granito $(0,84$ a 0,90$)$ e muito elevadas nos leucogranitos $(0,97$ a 0,99$)$. Os conteúdos de $\mathrm{CaO}$ e $\mathrm{Na}_{2} \mathrm{O}$ são muito superiores no Leucogranodiorito Pantanal, comparado ao leucogranito, ocorrendo o inverso com o $\mathrm{K}_{2} \mathrm{O}$. Isso se reflete nas razões $\mathrm{K}_{2} \mathrm{O} / \mathrm{Na}_{2} \mathrm{O}$ (Tabela 2), que são muito elevadas nos leucogranitos $(1,31$ a 2,20) em relação ao Leucogranodiorito Pantanal, cujos valores são inferiores a 0,65. Já no hornblenda-biotita-granito, essa razão (1,04 a 1,42) é bem superior à do granodiorito, e tende a ser inferior à do leucogranito, embora haja ligeira superposição.

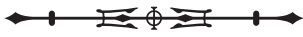


Tabela 2. Análises químicas em rochas do Leucogranodiorito Pantanal, leucogranitos e hornblenda-biotita-granitos (Hb-Bt-granito). Legenda: $\# \mathrm{Mg}=\% \mathrm{Mg} \mathrm{mol} /\left(\% \mathrm{Mg} \mathrm{mol}+\% \mathrm{Fe}_{2} \mathrm{O}_{3 \mathrm{t}} \mathrm{mol}\right)$.

(Continua)

\begin{tabular}{|c|c|c|c|c|c|c|c|c|c|c|c|c|c|c|c|}
\hline \multirow[b]{3}{*}{$\begin{array}{l}\text { Amostras } \\
\text { Elementos }\end{array}$} & \multicolumn{8}{|c|}{ Leucogranodiorito Pantanal } & \multicolumn{7}{|c|}{ Granitos de afinidade tipo-A } \\
\hline & \multicolumn{6}{|c|}{ Área-tipo } & \multicolumn{2}{|c|}{ Sudoeste } & \multicolumn{5}{|c|}{ Leucogranito } & \multicolumn{2}{|c|}{ Hb-Bt-granito } \\
\hline & $\begin{array}{c}\text { MYF- } \\
11\end{array}$ & $\begin{array}{c}\text { MYF- } \\
74\end{array}$ & $\begin{array}{c}\text { MYF- } \\
17 A\end{array}$ & $\begin{array}{l}\text { MYF- } \\
72\end{array}$ & $\begin{array}{c}\text { MYF- } \\
14 A\end{array}$ & $\begin{array}{l}\text { MYF- } \\
24 B\end{array}$ & $\begin{array}{c}\text { ADE- } \\
18\end{array}$ & $\begin{array}{c}\text { CDGW- } \\
112\end{array}$ & $\begin{array}{l}\text { MYF- } \\
13 B\end{array}$ & $\begin{array}{l}\text { MYF- } \\
13 C\end{array}$ & $\begin{array}{c}\text { MYF- } \\
15 B\end{array}$ & $\begin{array}{c}\text { MYF- } \\
14 \mathrm{~B}\end{array}$ & $\begin{array}{c}\text { MYF- } \\
13 \mathrm{~A}\end{array}$ & $\begin{array}{c}\text { MYF- } \\
77\end{array}$ & $\begin{array}{c}\text { MYF- } \\
78\end{array}$ \\
\hline $\mathrm{SiO}_{2}$ & 72,38 & 72,64 & 72,65 & 72,78 & 73,07 & 73,62 & 72,18 & 6 & 75,34 & 75,61 & 77,19 & 77,60 & 77,97 & 69,07 & 72,00 \\
\hline $\mathrm{TiO}_{2}$ & 0,20 & 0,21 & 0,15 & 0,16 & 0,16 & 0,12 & 0,17 & 0,16 & 0,04 & 0,07 & 0,02 & 0,03 & 0,04 & 0,63 & 0,40 \\
\hline $\mathrm{Al}_{2} \mathrm{O}_{3}$ & 15,52 & 15,02 & 15,01 & 15,17 & 15,03 & 14,51 & 15,47 & 15,36 & 12,71 & 12,84 & 12,52 & 12,16 & 11,66 & 13,64 & 13,08 \\
\hline $\mathrm{Fe}_{2} \mathrm{O}_{3 \mathrm{t}}$ & 1,63 & 1,93 & 1,55 & 1,58 & 1,57 & 1,40 & 1,53 & 1,50 & 1,33 & 1,26 & 1,27 & 1,00 & 1,60 & 4,96 & 3,97 \\
\hline $\mathrm{MnO}$ & 0,02 & 0,03 & 0,02 & 0,02 & 0,02 & 0,02 & 0,02 & 0,02 & 0,01 & 0,01 & 0,01 & 0,01 & 0,01 & 0,05 & 0,03 \\
\hline $\mathrm{MgO}$ & 0,44 & 0,50 & 0,37 & 0,37 & 0,37 & 0,36 & 0,37 & 0,31 & 0,02 & 0,03 & 0,03 & 0,01 & 0,02 & 0,88 & 0,39 \\
\hline $\mathrm{CaO}$ & 2,21 & 2,13 & 2,02 & 2,00 & 1,88 & 2,08 & 2,31 & 2,25 & 0,93 & 0,69 & 0,60 & 0,65 & 0,63 & 2,76 & 1,35 \\
\hline $\mathrm{Na}_{2} \mathrm{O}$ & 4,90 & 4,91 & 4,76 & 4,64 & 4,83 & 4,32 & 5,31 & 5,25 & 2,79 & 3,33 & 3,40 & 3,40 & 3,14 & 3,58 & 3,28 \\
\hline $\mathrm{K}_{2} \mathrm{O}$ & 2,03 & 2,07 & 2,56 & 2,69 & 2,63 & 2,72 & 1,98 & 2,02 & 6,14 & 5,48 & 4,46 & 4,56 & 4,17 & 3,72 & 4,66 \\
\hline $\mathrm{P}_{2} \mathrm{O}_{5}$ & 0,06 & 0,04 & 0,03 & 0,04 & 0,03 & 0,02 & 0,04 & 0,04 & 0,01 & 0,01 & 0,01 & 0,02 & 0,02 & 0,16 & 0,06 \\
\hline $\mathrm{FeO}_{\mathrm{t}}$ & 1,47 & 1,74 & 1,39 & 1,42 & 1,41 & 1,26 & 1,38 & 1,35 & 1,20 & 1,13 & 1,14 & 0,90 & 1,44 & 4,46 & 3,57 \\
\hline PF & 0,40 & 0,30 & 0,70 & 0,30 & 0,20 & 0,60 & 0,40 & 0,40 & 0,50 & 0,50 & 0,40 & 0,50 & 0,60 & 0,20 & 0,5 \\
\hline Total & 99,39 & 99,48 & 99,12 & 99,45 & 99,59 & 99,17 & 99,38 & 99,37 & 99,32 & 99,33 & 99,51 & 99,44 & 99,26 & 99,68 & 99,72 \\
\hline $\mathrm{Ba}$ & 990 & 898 & 1.024 & 1.047 & 905 & 1.610 & 929 & 1.064 & 133 & 151 & 63 & 45 & 61 & 1.234 & 1.018 \\
\hline $\mathrm{Sr}$ & 505 & 473,6 & 360,3 & 457,8 & 394,2 & 471,3 & 557,2 & 562,9 & 28 & 39,7 & 34,3 & 22,3 & 30,4 & 200,8 & 123,0 \\
\hline $\mathrm{Rb}$ & 42,2 & 67,5 & 62 & 69,1 & 102 & 57,5 & 44 & 41,7 & 337,8 & 337,1 & 233,3 & 300,9 & 239,8 & 93,6 & 163,7 \\
\hline $\mathrm{Zr}$ & 127,6 & 140,1 & \begin{tabular}{|l|l}
117,2 \\
\end{tabular} & 112,6 & 99,7 & 109,3 & 105,8 & 108,0 & 221,9 & \begin{tabular}{|l}
155,6 \\
\end{tabular} & 110 & 135,5 & 138,9 & 616,6 & 385,4 \\
\hline$Y$ & 3,6 & 4,8 & 4,1 & 3,5 & 3,1 & 2,2 & 3 & 2,7 & 96,1 & 212,9 & 105,7 & 102,5 & 85,2 & 29,6 & 57,5 \\
\hline $\mathrm{Hf}$ & 3,6 & 4,0 & 3,1 & 3,1 & 2,7 & 3,5 & 3 & 2,9 & 14,1 & 9,1 & 8,2 & 8,0 & 8,7 & 13,4 & 10,5 \\
\hline $\mathrm{Nb}$ & 2,1 & 4,7 & 4,4 & 3,5 & 3 & 2,3 & 2,6 & 1,4 & 50,1 & 46,7 & 38,3 & 45,7 & 46,3 & 13,4 & 19,2 \\
\hline $\mathrm{Ta}$ & 0,3 & 0,6 & 0,6 & 0,8 & 0,5 & 0,5 & 0,5 & 0,4 & 2,9 & 3,5 & 4,3 & 2,8 & 2,7 & 1,1 & 1,3 \\
\hline $\mathrm{Ni}$ & 2,8 & 3,5 & 3,2 & 2,6 & 2,2 & 3,1 & 1,8 & - & 1,4 & 1,6 & 2,3 & 1,6 & 3,9 & 14,3 & 4,2 \\
\hline$U$ & 0,3 & 2,2 & 0,8 & 1,0 & 0,7 & 0,3 & 0,5 & 0,6 & 20,4 & 16,2 & 15,8 & 13,9 & 15,1 & 1,6 & 3,1 \\
\hline Th & 5 & 4,3 & 8,7 & 6,3 & 5,4 & - & 4,2 & 3,5 & 84,6 & 62,5 & 53,3 & 82,9 & 71,5 & 11,1 & 20,9 \\
\hline $\mathrm{Zn}$ & 40 & 51 & 36 & 37 & 44 & 32 & 40 & 25 & 10 & 16 & 2 & 6 & 3 & 30 & 34 \\
\hline $\mathrm{Ga}$ & 17,9 & 19,1 & 17,4 & 17,9 & 17,3 & 15,5 & 18,5 & 17,3 & 20,3 & 21,1 & 21,5 & 20,6 & 20 & 17,1 & 17,6 \\
\hline La & 29,6 & 22,5 & 33,9 & 24,5 & 18,9 & 20,3 & 15,4 & 22,4 & 73,4 & 56,1 & 16,8 & 33,1 & 27 & 39,5 & 85,7 \\
\hline $\mathrm{Ce}$ & 40,8 & 38,2 & 61 & 43,6 & 32,8 & 37,2 & 26,5 & 36,0 & 157,4 & 114,6 & 43,1 & 75,2 & 41,7 & 83,9 & 167,1 \\
\hline $\mathrm{Pr}$ & 4,81 & 3,95 & 5,95 & 4,41 & 3,52 & 3,69 & 2,89 & 4,44 & 20,52 & \begin{tabular}{|l|}
16,04 \\
\end{tabular} & 5,38 & 9,52 & 6,79 & 10,11 & 19,8 \\
\hline $\mathrm{Nd}$ & 16,7 & 12,6 & 20 & 14,6 & 12,7 & 10,8 & 9,8 & 15,4 & 67,9 & 62,9 & 19,1 & 35,1 & 23,2 & 39,5 & 74,7 \\
\hline $\mathrm{Sm}$ & 2,18 & 1,81 & 2,65 & 1,83 & 1,55 & 1,5 & 1,36 & 1,93 & 15,7 & 16,76 & 5,97 & 9,43 & 5,78 & 7,42 & 12,3 \\
\hline $\mathrm{Eu}$ & 0,6 & 0,52 & 0,49 & 0,49 & 0,48 & 0,51 & 0,44 & 0,58 & 0,37 & 0,38 & 0,13 & 0,14 & 0,24 & 1,32 & 1,38 \\
\hline $\mathrm{Gd}$ & 1,56 & 1,24 & 1,72 & 1,33 & 1,19 & 1,02 & 0,93 & 1,06 & 14,43 & 21,24 & 7,41 & 9,91 & 6,1 & 6,65 & 10,91 \\
\hline
\end{tabular}


Tabela 2.

\begin{tabular}{|c|c|c|c|c|c|c|c|c|c|c|c|c|c|c|c|}
\hline \multirow{3}{*}{$\begin{array}{l}\text { Amostras } \\
\text { Elementos }\end{array}$} & \multicolumn{8}{|c|}{ Leucogranodiorito Pantanal } & \multicolumn{7}{|c|}{ Granitos de afinidade tipo-A } \\
\hline & \multicolumn{6}{|c|}{ Área-tipo } & \multicolumn{2}{|c|}{ Sudoeste } & \multicolumn{5}{|c|}{ Leucogranito } & \multicolumn{2}{|c|}{ Hb-Bt-granito } \\
\hline & $\begin{array}{c}\text { MYF- } \\
11\end{array}$ & $\begin{array}{c}\text { MYF- } \\
74\end{array}$ & $\begin{array}{l}\text { MYF- } \\
17 A\end{array}$ & $\begin{array}{l}\text { MYF- } \\
72\end{array}$ & $\begin{array}{l}\text { MYF- } \\
14 \mathrm{~A}\end{array}$ & $\begin{array}{l}\text { MYF- } \\
24 B\end{array}$ & $\begin{array}{l}\text { ADE- } \\
18\end{array}$ & $\begin{array}{c}\text { CDGW- } \\
112\end{array}$ & $\begin{array}{l}\text { MYF- } \\
13 B\end{array}$ & $\begin{array}{l}\text { MYF- } \\
13 C\end{array}$ & $\begin{array}{l}\text { MYF- } \\
15 B\end{array}$ & $\begin{array}{l}\text { MYF- } \\
14 B\end{array}$ & $\begin{array}{l}\text { MYF- } \\
\text { 13A }\end{array}$ & $\begin{array}{c}\text { MYF- } \\
77\end{array}$ & $\begin{array}{c}\text { MYF- } \\
78\end{array}$ \\
\hline $\mathrm{Tb}$ & 0,14 & 0,15 & 0,17 & 0,13 & 0,11 & 0,09 & 0,11 & 0,12 & 2,27 & 3,61 & 1,75 & 1,94 & 1,37 & 0,96 & 1,61 \\
\hline Dy & 0,67 & 0,88 & 1,1 & 0,67 & 0,59 & 0,49 & 0,65 & 0,47 & 14,6 & 24,78 & 13,86 & 13,38 & 10,83 & 5,47 & 10,07 \\
\hline Ho & 0,09 & 0,15 & 0,13 & 0,1 & 0,09 & 0,06 & 0,07 & 0,06 & 2,84 & 5,05 & 3,27 & 2,93 & 2,41 & 1,01 & 2,02 \\
\hline $\mathrm{Er}$ & 0,24 & 0,38 & 0,3 & 0,26 & 0,21 & 0,21 & 0,27 & 0,20 & 8,86 & 15,08 & 11,99 & 9,9 & 8,47 & 2,83 & 6,12 \\
\hline $\mathrm{Tm}$ & 0,03 & 0,05 & 0,05 & 0,05 & 0,02 & 0,02 & 0,04 & 0,04 & 1,34 & 2,43 & 2,27 & 1,66 & 1,44 & 0,42 & 0,93 \\
\hline $\mathrm{Yb}$ & 0,23 & 0,46 & 0,3 & 0,41 & 0,21 & 0,26 & 0,17 & 0,19 & 9,06 & 16,44 & 16,71 & 11,6 & \begin{tabular}{|l|}
10,37 \\
\end{tabular} & 2,69 & 6,23 \\
\hline Lu & 0,03 & 0,07 & 0,04 & 0,06 & 0,03 & 0,02 & 0,03 & 0,03 & 1,35 & 2,48 & 2,64 & 1,64 & 1,51 & 0,4 & 0,87 \\
\hline A/CNK & 1,09 & 1,06 & 1,05 & 1,07 & 1,06 & 1,05 & 1,03 & 1,03 & 0,98 & 1,01 & 1,09 & 1,04 & 1,08 & 0,91 & 1,01 \\
\hline$\# M g$ & 0,35 & 0,34 & 0,32 & 0,32 & 0,32 & 0,34 & 0,32 & 0,29 & 0,03 & 0,05 & 0,04 & 0,02 & 0,02 & 0,26 & 0,16 \\
\hline $\mathrm{Rb} / \mathrm{Sr}$ & 0,08 & 0,14 & 0,17 & 0,15 & 0,26 & 0,12 & 0,08 & 0,07 & 12,06 & 8,49 & 6,80 & 13,49 & 7,89 & 0,47 & 1,33 \\
\hline $\mathrm{Sr} / \mathrm{Ba}$ & 0,51 & 0,53 & 0,35 & 0,44 & 0,44 & 0,29 & 0,60 & 0,53 & 0,21 & 0,26 & 0,54 & 0,50 & 0,50 & 0,16 & 0,12 \\
\hline $\mathrm{Sr} / \mathrm{Y}$ & 140,28 & 98,67 & 87,88 & 130,80 & 127,16 & 214,23 & 185,73 & 208,48 & 0,29 & 0,19 & 0,32 & 0,22 & 0,36 & 6,78 & 2,14 \\
\hline $\mathrm{Nb} / \mathrm{Ta}$ & 7,00 & 7,83 & 7,33 & 4,38 & 6,00 & 4,60 & 5,20 & 3,50 & 17,28 & 13,34 & 8,91 & 16,32 & 17,15 & 12,18 & 14,77 \\
\hline $\begin{array}{c}\mathrm{FeO}_{\mathrm{f}} \\
\left(\mathrm{FeO}_{\mathrm{t}}+\mathrm{MgO}\right)\end{array}$ & 0,77 & 0,78 & 0,79 & 0,79 & 0,79 & 0,78 & 0,79 & 0,81 & 0,98 & 0,97 & 0,97 & 0,99 & 0,99 & 0,84 & 0,90 \\
\hline $\mathrm{K} / \mathrm{O} / \mathrm{Na}_{2} \mathrm{O}$ & 0,41 & 0,42 & 0,54 & 0,58 & 0,54 & 0,63 & 0,37 & 0,38 & 2,20 & 1,65 & 1,31 & 1,34 & 1,33 & 1,04 & 1,42 \\
\hline$(\mathrm{La} / \mathrm{Yb})_{N}$ & 86,87 & 33,02 & 76,27 & 40,33 & 60,75 & 52,70 & 61,15 & 79,58 & 5,47 & 2,30 & 0,68 & 1,93 & 1,76 & 9,91 & 9,29 \\
\hline$(\mathrm{La} / \mathrm{Sm})_{\mathrm{N}}$ & 8,55 & 7,83 & 8,05 & 8,43 & 7,68 & 8,52 & 7,13 & 7,31 & 2,94 & 2,11 & 1,77 & 2,21 & 2,94 & 3,35 & 4,39 \\
\hline$(\mathrm{Ga} / \mathrm{Yb})_{\mathrm{N}}$ & 5,48 & 2,18 & 4,63 & 2,62 & 4,58 & 3,17 & 4,42 & 4,51 & 1,29 & 1,04 & 0,36 & 0,69 & 0,48 & 2,00 & 1,42 \\
\hline (Eu/Eu*) & 0,95 & 1,01 & 0,66 & 0,92 & \begin{tabular}{|l|}
1,04 \\
\end{tabular} & 1,19 & 1,13 & 1,13 & 0,07 & 0,06 & 0,06 & 0,04 & 0,12 & 0,56 & 0,36 \\
\hline
\end{tabular}

No que diz respeito aos elementos-traço (Figura 10), a sua distribuição é controlada pelas fases minerais fracionadas durante a gênese e cristalização do magma. Por isso, a sua variação reflete a diferenciação magmática e pode subsidiar a interpretação dos processos responsáveis por sua evolução (Hanson, 1978). Assim como observado para os elementos maiores, as unidades estudadas apresentam diferenças expressivas no conteúdo dos elementos-traço.

O Leucogranodiorito Pantanal possui altos conteúdos de $\mathrm{Ba}$ (898 a 1.064 ppm, com uma amostra exibindo teor de 1.610 ppm) e Sr (394 a 563 ppm), e baixos de Rb (41 a 102 ppm, geralmente $<70$ ppm). $\bigcirc$ hornblenda-biotitagranito mostra teores similares de $\mathrm{Ba}(1.018$ a $1.234 \mathrm{ppm})$, mais elevados de $\mathrm{Rb}$ (93 a 164 ppm) e mais baixos de Sr (123 a 201 ppm) do que o Leucogranodiorito Pantanal. Os leucogranitos, por sua vez, possuem valores extremamente baixos de Ba (45 a 151 ppm) e Sr (22 a 40 ppm) e altos de Rb (233 a 338 ppm). Nos diagramas de Harker, os leucogranodioritos apresentam pouca variação em $\mathrm{Ba}, \mathrm{Zr}$, $\mathrm{Nb}$ e Y (Figuras 10A, 10D-10F), e consequentemente baixos coeficientes de correlação de Pearson. Já o Rb tende a mostrar correlação positiva moderada com a $\mathrm{SiO}_{2}$, enquanto que o $\mathrm{Sr}$ exibe correlação fracamente negativa. Nos leucogranitos, Ba e Rb têm correlação fortemente negativa, enquanto que $\mathrm{Zr}$ e $\mathrm{Y}$ exibem correlação moderadamente negativa, e Sr e Nb fracamente negativa com a sílica. 


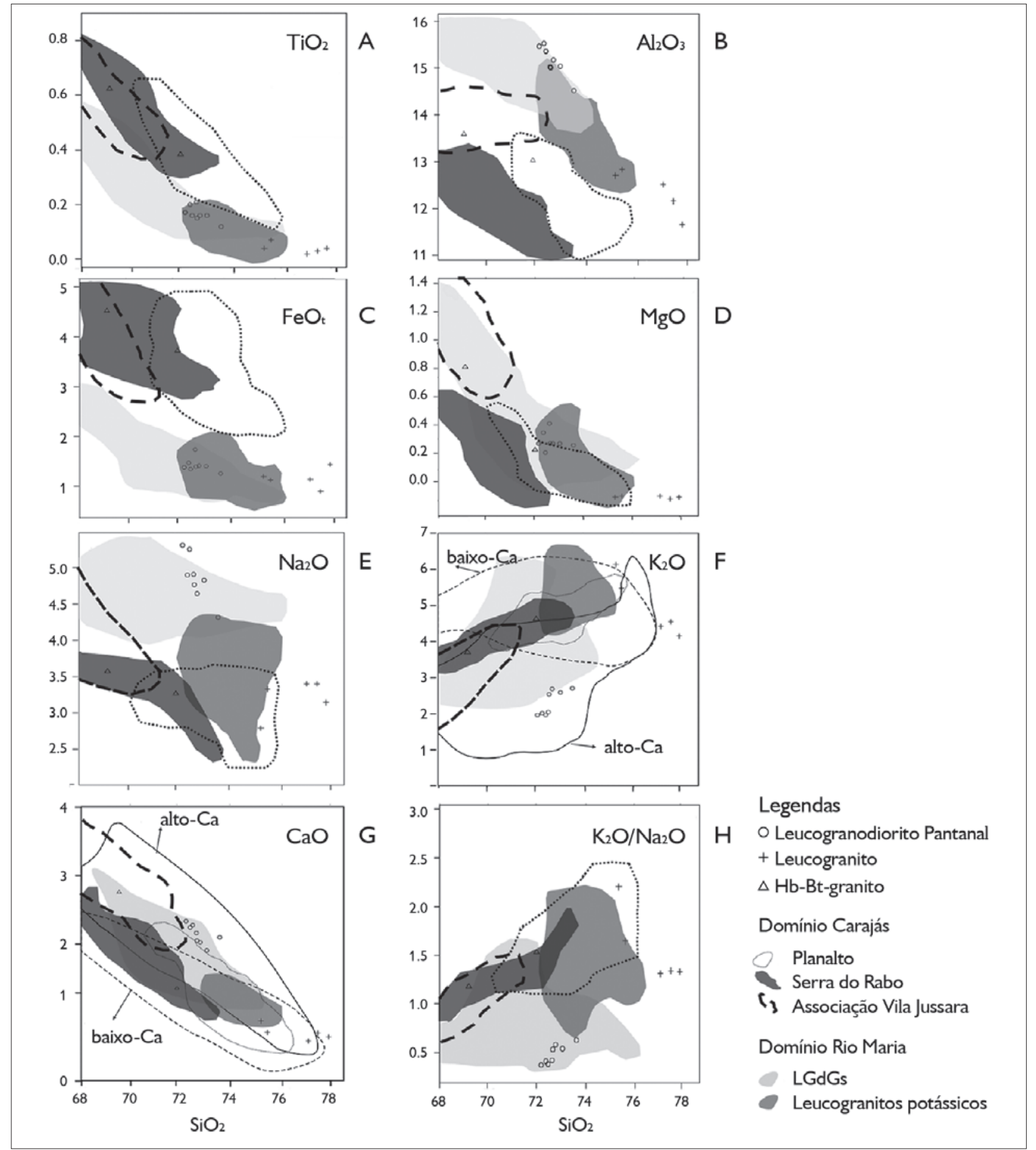

Figura 9. Diagramas de Harker para os óxidos de elementos maiores do Leucogranodiorito Pantanal e granitos associados, em comparação com leucogranodioritos-granitos (Almeida et al., 2010) e leucogranitos potássicos (Almeida et al., 2013) do Domínio Rio Maria, e com a Suíte Planalto (Feio et al., 2012), Granito Serra do Rabo (Sardinha et al., 2006) e Suíte Vila Jussara (Silva et al., comunicação pessoal, 2013) do Domínio Carajás. Campos dos granitos com alto Ca e baixo Ca do Cráton Yilgarn segundo Champion \& Sheraton (1997). A) TiO ; B) $\mathrm{Al}_{2} \mathrm{O}_{3}$; C) $\mathrm{FeO}_{\mathrm{t}}$; D) $\mathrm{MgO}$; E) $\mathrm{Na}_{2} \mathrm{O}$; F) $\mathrm{K}_{2} \mathrm{O}$; G) Alto $\left.\mathrm{CaO} ; \mathrm{H}\right) \mathrm{K}_{2} \mathrm{O} / \mathrm{Na}_{2} \mathrm{O}$. 


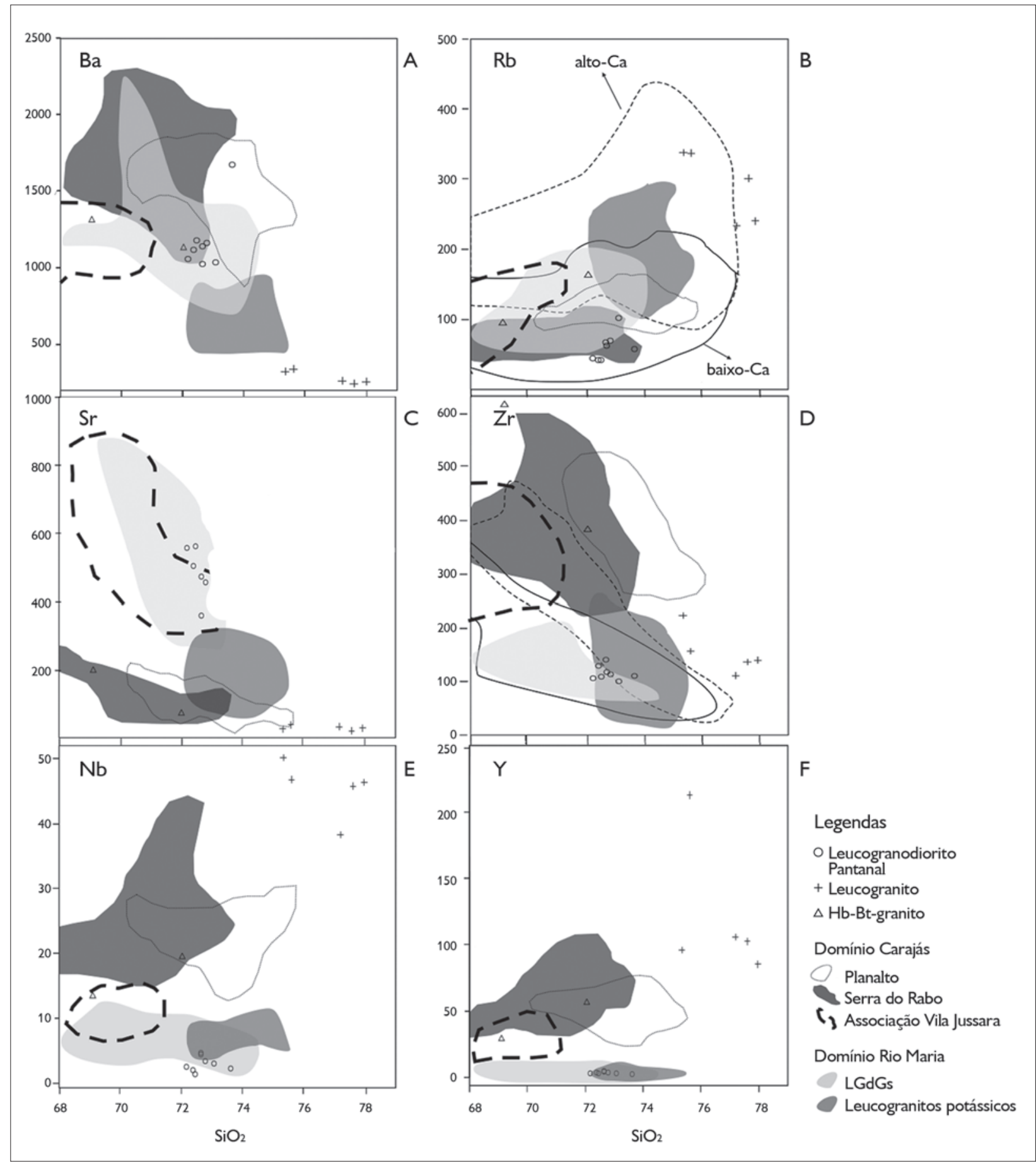

Figura 10. Diagramas de Harker para os elementos-traço do Leucogranodiorito Pantanal e granitos associados, em comparação com leucogranodioritos-granitos (Almeida et al., 2010) e leucogranitos potássicos (Almeida et al., 2013) do Domínio Rio Maria, e com a Suíte Planalto (Feio et al., 2012), Granito Serra do Rabo (Sardinha et al., 2006) e Suíte Vila Jussara (A. C. Silva, comunicação pessoal) do Domínio Carajás. Campos dos granitos arqueanos com alto Ca e baixo Ca do Cráton de Yilgarn (Champion \& Sheraton, 1997). A) Ba; B) Rb; C) $\mathrm{Sr}$; D) Zr; E) Nb; F) Y. 
No Leucogranodiorito Pantanal, as razões Rb/Sr $(<0,3)$ e $\mathrm{Nb} / \mathrm{Ta}(<8)$ são baixas, enquanto que as razões Sr/Y são elevadas (87,88 a 214,23; Tabela 2). O inverso ocorre para os leucogranitos, que possuem altas razões $\mathrm{Rb} /$ $\mathrm{Sr}$ e $\mathrm{Nb} / \mathrm{Ta}$ (6,8 a 12,06 e 8,91 a 17,28, respectivamente) e razões $\mathrm{Sr} / \mathrm{Y}$ extremamente reduzidas $(0,19$ a 0,36$)$. $\bigcirc$ hornblenda-biotita-granito (Tabela 2 ) exibe razões $\mathrm{Rb} / \mathrm{Sr}(0,47$ a 1,33) e $\mathrm{Sr} / \mathrm{Y}(2,14$ a 6,78) intermediárias entre os valores obtidos nas amostras de granodiorito e leucogranito, e razões $\mathrm{Nb} / \mathrm{Ta}(12,18$ a 14,77) que se superpõem àquelas fornecidas pelo leucogranito.

O Leucogranodiorito Pantanal é empobrecido nos elementos HFSE [(Tabela 2); Zr (99,7-140,1 ppm); Hf (2,74,0 ppm); Y (2,2-4,8 ppm); Nb (1,4-4,7 ppm) e Ta (0,3-0,8 ppm)], quando comparado ao leucogranito $[\mathrm{Zr}(110-222$ ppm); Hf(8,0-14 ppm); Y (85-213 ppm); Nb (38,3-50 ppm) e Ta (2,7-4,3 ppm)] e ao hornblenda-biotita-granito [ $\mathrm{Zr}$ (385-616 ppm); Hf(10,5-13,4 ppm); Y (29,6-57,5 ppm); Nb (13,4-19,2 ppm) e Ta (1,1-1,3 ppm)], que são enriquecidos nesses elementos. Isso indica afinidade com granitos tipo-A para os leucogranitos e hornblenda-biotita-granito.

Os conteúdos de elementos terras raras (ETR) foram normalizados pelos valores dos condritos conforme Evensen et al., 1978 (Figura 11). Tal como verificado para os demais elementos, o Leucogranodiorito Pantanal e os leucogranitos revelaram teores e padrões distintos para os ETR.

O Leucogranodiorito Pantanal possui, de maneira geral, comportamento dos ETR bastante homogêneo, com acentuado enriquecimento dos ETR leves em relação aos ETR pesados, indicativo de fracionamento expressivo dos ETR pesados durante a formação ou diferenciação dos seus magmas. Apresenta altas razões $(\mathrm{La} / \mathrm{Yb})_{\mathrm{N}}(33,02-86,87)$, com anomalias positivas ou negativas de Eu ausentes ou incipientes (Eu/Eu* $=0,92-1,19$, com um valor isolado de 0,66; Tabela 2). Exibe ainda concavidade no padrão de ETR pesados, o que indica provável influência de fracionamento de anfibólio durante sua evolução.

Os leucogranitos, por sua vez, são mais enriquecidos em ETR (Tabela 2) e revelam padrões extremamente

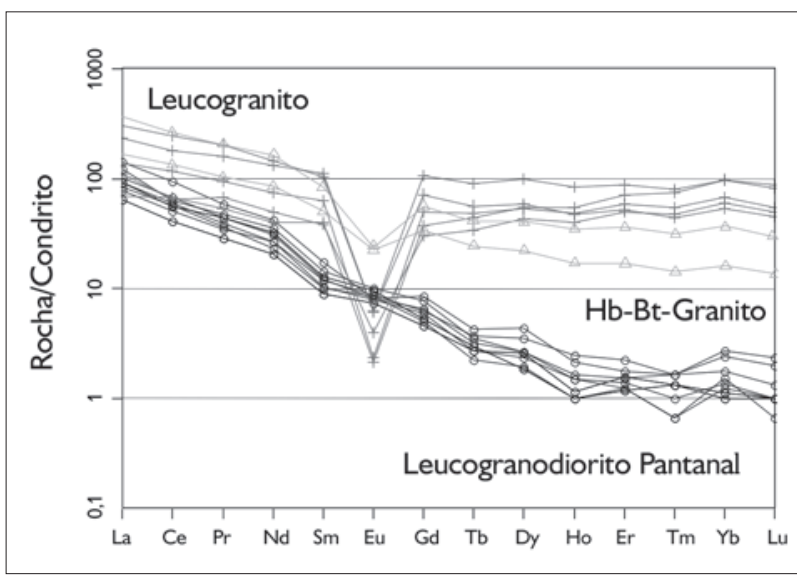

Figura 11. Padrão dos ETR do Leucogranodiorito Pantanal, leucogranito e hornblenda-biotita-granito, normalizados em relação ao condrito (Evensen et al., 1978).

distintos dos observados para o Leucogranodiorito Pantanal. Exibem pequeno enriquecimento em ETR leves em relação aos pesados, anomalia negativa de $\mathrm{Eu}\left(\mathrm{Eu} / \mathrm{Eu}{ }^{*}=0,04-0,12\right)$ extremamente acentuada e não revelam fracionamento significativo dos ETR pesados $\left.\left[(\mathrm{La} / \mathrm{Yb})_{\mathrm{N}}=0,68-5,47\right)\right]$, determinando, assim, padrões em 'asa-de-gaivota' (Figura 11), típicos de granitos derivados de magmas evoluídos.

hornblenda-biotita-granito também é mais enriquecido em ETR do que o Leucogranodiorito Pantanal e mostra conteúdo total similar ao dos leucogranitos (Tabela 2). Os seus conteúdos em ETR leves se superpõem e os de ETR pesados são ligeiramente inferiores aos observados nos leucogranitos. Exibe anomalias negativas de Eu moderadas $\left(E u / E u^{*}=0,36\right.$ a 0,56) e ligeiro aumento no fracionamento dos pesados $\left[(\mathrm{La} / \mathrm{Yb})_{\mathrm{N}}=9,29\right.$ a 9,91$]$ em relação aos leucogranitos (Figura 11).

\section{CARACTERIZAÇÃO DA SÉRIE MAGMÁTICA}

As composições químicas das rochas estudadas foram utilizadas para avaliar a afinidade geoquímica de cada granito em termos de séries magmáticas. No diagrama $\left(\mathrm{FeO}_{t} /\right.$ $\mathrm{MgO}$ versus $\mathrm{Zr}+\mathrm{Nb}+\mathrm{Ce}+\mathrm{Y}$ ), utilizado para discriminação de granitos tipo-A dos granitos tipo I, S e M (Whalen et al., 1987), as amostras de leucogranito e do hornblenda-

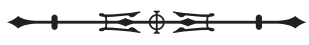


biotita-granito situam-se no campo dos granitos tipo-A, e as amostras do Leucogranodiorito Pantanal no limite entre os campos de granitos dos tipos I, S e M não fracionados e I e $S$ fracionados (Figura 12A). O diagrama FeO/ $/\left(\mathrm{FeO}_{\mathrm{t}}+\mathrm{MgO}\right)$ versus $\mathrm{Al}_{2} \mathrm{O}_{3}$, proposto para diferenciar granitos tipo-A oxidados e reduzidos entre si, bem como de associações cálcio-alcalinas (Dall'Agnol \& Oliveira, 2007), mostra que os leucogranitos plotam exclusivamente no campo dos granitos tipo-A reduzidos, enquanto que o hornblendabiotita-granito plota no campo dos granitos tipo-A oxidados e o Leucogranodiorito Pantanal exibe caráter cálcio-alcalino e oxidado (Figura 12B).

No diagrama normativo Ab-An-Or (Figura 12C; O'Connor, 1965, com campos de Barker, 1979), as amostras do Leucogranodiorito Pantanal plotam exclusivamente no campo dos trondhjemitos, isso devido ao seu baixo conteúdo de anortita e ortoclásio normativos. Já o leucogranito e o hornblenda-biotita-granito situamse coerentemente no campo dos granitos. O índice de Shand (1950) (Ver A/CNK, Tabela 2) revela que, de modo geral, os leucogranodioritos e leucogranitos são fracamente peraluminosos, embora os leucogranitos possam ter evoluído a partir de associação metaluminosa, pois uma de suas amostras tem esse caráter. A amostra portadora de anfibólio do hornblenda-biotita-granito plota coerentemente no campo metaluminoso, enquanto que aquela de biotita-granito é levemente peraluminosa (Figura 12D). No diagrama (100* $\left(\mathrm{MgO}+\mathrm{FeO}+\mathrm{TiO}_{2}\right) / \mathrm{SiO}_{2}$ versus $\left(\mathrm{Al}_{2} \mathrm{O}_{3}+\mathrm{CaO}\right) /\left(\mathrm{FeO}+\mathrm{K}_{2} \mathrm{O}+\mathrm{Na}_{2} \mathrm{O}\right)$ (Sylvester, 1989), o Leucogranodiorito Pantanal demonstra afinidade com rochas cálcio-alcalinas, enquanto que os leucogranitos plotam no campo das rochas alcalinas fortemente fracionadas e o hornblenda-biotita-granito no campo das rochas alcalinas (Figura 12E). O Leucogranodiorito Pantanal, os leucogranitos e o hornblenda-biotita-granito também se situam em campos distintos nos diagramas $R_{1}-R_{2}$ (De la Roche et al., 1980; Figura 12F) e P-Q (Debon \& Le Fort, 1983; Figura 12G). Neste último, os leucogranodioritos situam-se nos campos de trondhjemitos e granodioritos, os hornblenda-biotita-granitos variam de monzogranitos a sienogranitos e os leucogranitos distribuem-se exclusivamente no campo dos sienogranitos.

\section{DISCUSSÃO}

\section{COMPARAÇÕES DO LEUCOGRANODIORITO PANTANAL COM LEUCOGRANITOIDES DO DOMÍNIO RIO MARIA, DA PROVIINCIA CARAJÁS, E LEUCOGRANITOIDES AFINS DO CRÁTON YILGARN}

A comparação do Leucogranodiorito Pantanal com os granitoides que ocorrem no Domínio Rio Maria e no Cráton Yilgarn será feita com base nos dados sumarizados por Almeida et al. (2010, 2013), os quais abrangem a Suíte Guarantã, formada por leucogranodioritos e granitos (LGdG) de $\sim 2,87 \mathrm{Ga}$, pertencentes aos plútons Guarantã, Azulona e Trairão; o Granodiorito Grotão (Almeida et al., 2010; Guimarães et al., comunicação pessoal); os granitos de alto $\mathrm{Ca}$ (também denominados de TTG transicionais) e baixo Ca do Cráton Yilgarn (Champion \& Sheraton, 1997; Champion \& Smithies, 2003); os leucogranitos potássicos de 2,87-2,86 Ga (plútons Xinguara e Mata Surrão e rochas similares; Duarte \& Dall'Agnol, 1996; Leite et al., 1999; Almeida et al., 2013).

Nos diferentes diagramas geoquímicos (Figuras 9 e 10), as amostras do Leucogranodiorito Pantanal estão concentradas sistematicamente nos campos delimitados pelos LGdG do Domínio Rio Maria (Suíte Guarantã e leucogranodioritos e granitos afins) e granitos de alto Ca de Yilgarn, com exceção apenas para $\mathrm{K}_{2} \mathrm{O}$ e $\mathrm{Rb}$, os quais tendem a ser mais baixos do que nos LGdD. Com relação aos ETR, nos LGdG foram definidos três grupos com base nas razões La/Yb (altas, médias e baixas razões La/Yb; Almeida et al., 2010), de modo semelhante ao que foi observado nos TTG do Domínio Rio Maria (Almeida et al., 2011). O Leucogranodiorito Pantanal apresenta maior correspondência com o grupo de alta razão La/Yb da Suíte Guarantã (Figura 13A), havendo similaridade em termos 


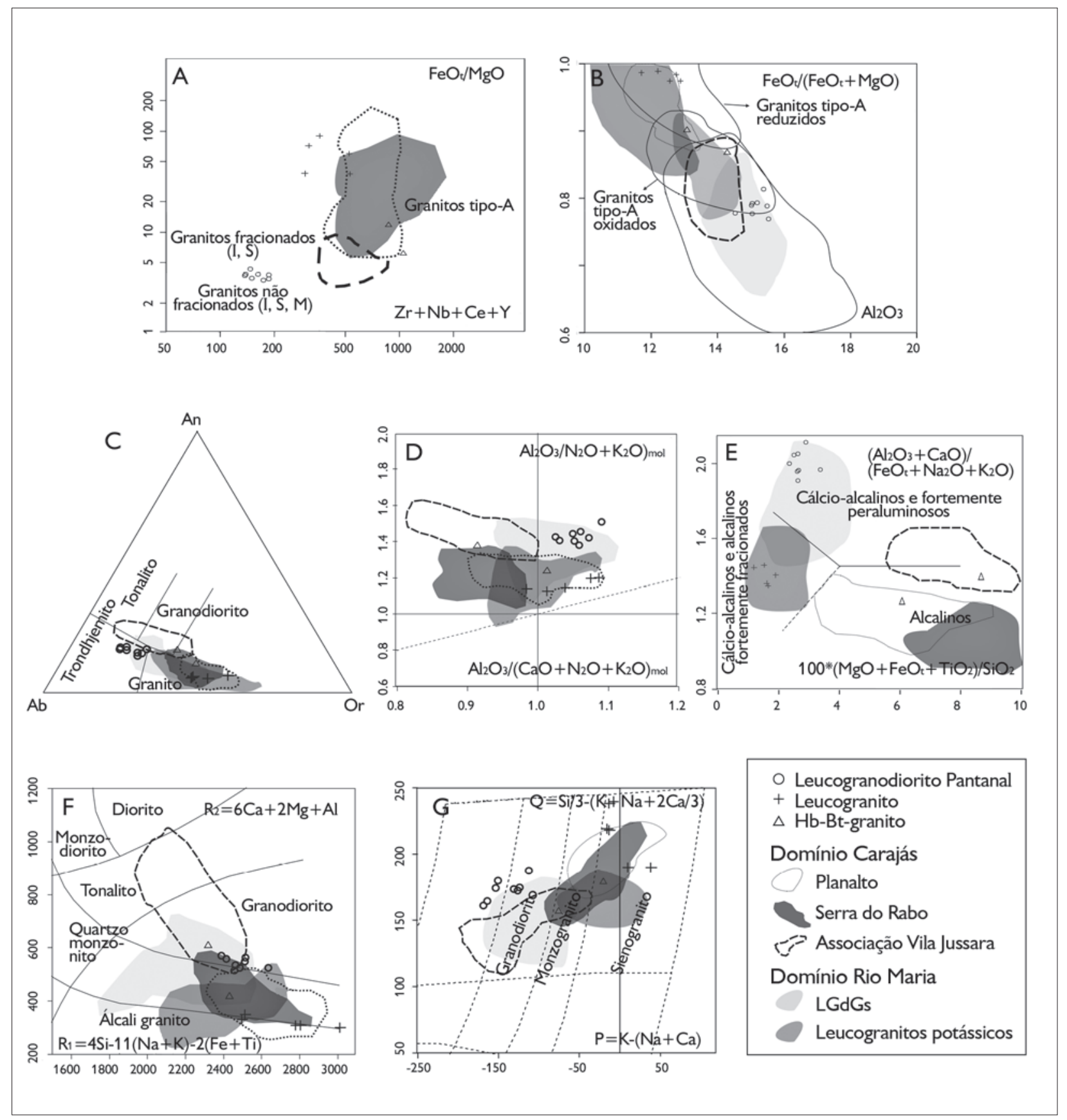

Figura 12. Caracterização geoquímica do Leucogranodiorito Pantanal e leucogranitos associados. A) Diagrama $(\mathrm{Zr}+\mathrm{Nb}+\mathrm{Ce}+\mathrm{Y}$ versus $\mathrm{FeO} / \mathrm{MgO}$; Whalen et al., 1987); B) diagrama $\mathrm{FeO}_{t} /\left(\mathrm{FeO}_{t}+\mathrm{MgO}\right.$ ) versus $\mathrm{Al}_{2} \mathrm{O}_{3}$, mostrando os campos dos granitos tipo-A oxidados e reduzidos, bem como de granitoides cálcio-alcalinos (Dall'Agnol \& Oliveira, 2007); C) diagrama An-Ab-Or normativo (O'Connor, 1965, com campos de Barker, 1979); D) diagrama $\left[\mathrm{Al}_{2} \mathrm{O}_{3} /\left(\mathrm{Na}_{2} \mathrm{O}+\mathrm{K}_{2} \mathrm{O}\right)\right]_{\mathrm{mol}}$ versus $\left[\mathrm{Al}_{2} \mathrm{O}_{3} /\left(\mathrm{CaO}+\mathrm{Na}_{2} \mathrm{O}+\mathrm{K}_{2} \mathrm{O}\right)\right]_{\mathrm{mol}}$ (Maniar \& Piccoli, 1989); E) diagrama de discriminação de granitos (Sylvester, 1989); F) diagrama $R_{1}-R_{2}$ (De la Roche et al., 1980); G) diagrama P-Q (Debon \& Le Fort, 1983). Fontes dos dados utilizados para comparação: leucogranodioritos-granitos (LGdG; Almeida et al., 2010); leucogranitos potássicos (Almeida et al., 2013), do Domínio Rio Maria; Suíte Planalto (Feio et al., 2012); Granito Serra do Rabo (Sardinha et al., 2006) e Suíte Vila Jussara (Silva et al., comunicação pessoal, 2013), do Domínio Carajás.




do fracionamento de ETR pesados, do comportamento do Eu e também da presença de padrão côncavo no segmento dos ETR pesados, indicativo do fracionamento de anfibólio durante a evolução desses magmas. Quanto ao Granodiorito Grotão e TTG transicionais do Cráton
Yilgarn, os padrões destes são muito similares e algo distintos daqueles do Leucogranodiorito Pantanal, pois revelam um enriquecimento relativo em ETR e ausência de concavidade nos ETR pesados (Figuras 13B, 13E). Os dois primeiros exibem maiores analogias com o grupo
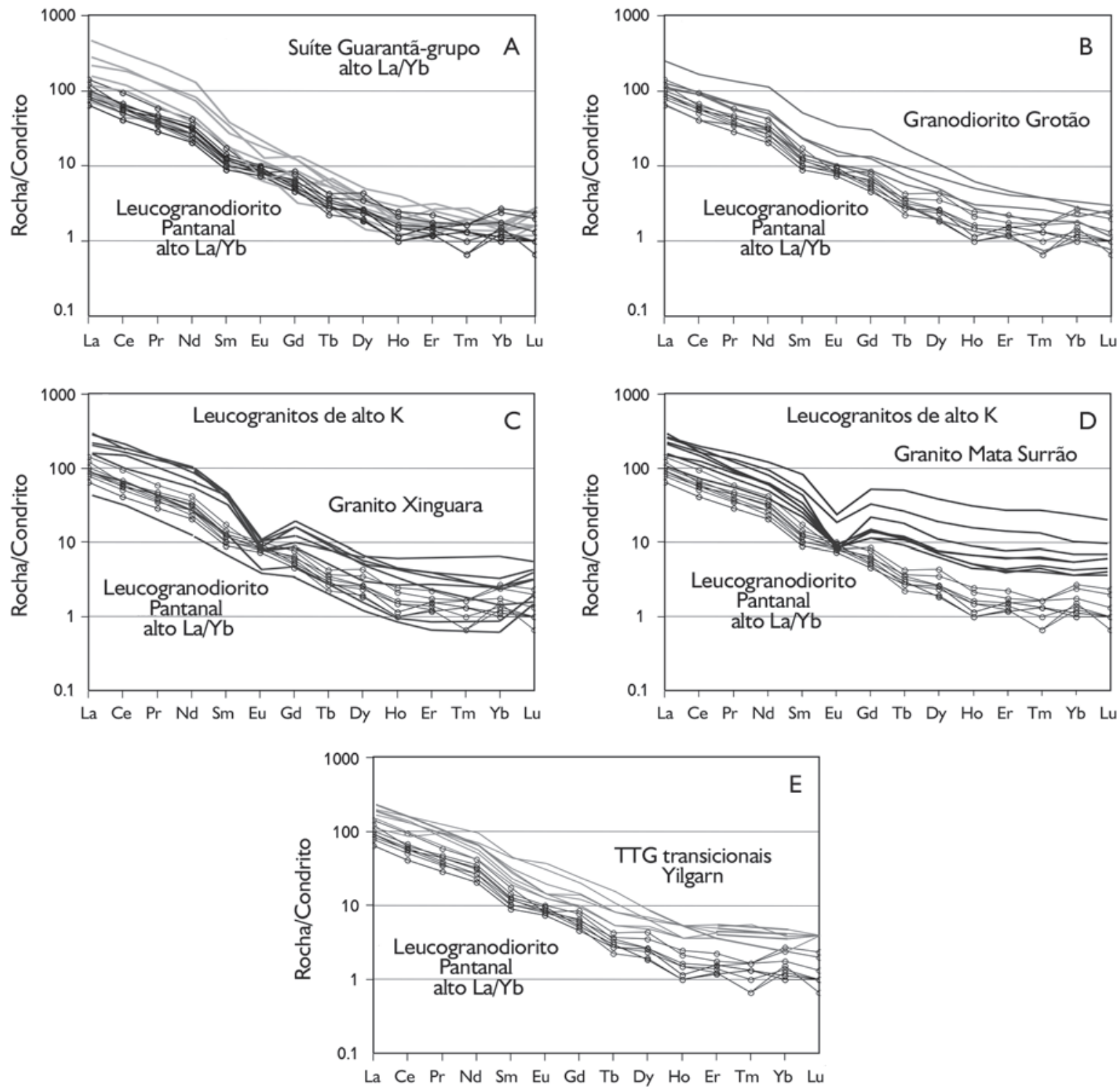

Figura 13. Padrões de elementos terras raras do Leucogranodiorito Pantanal comparados com os da Suíte Guarantã e Granodiorito Grotão (A e B), e os leucogranitos potássicos (C e D; Almeida et al., 2010, 2013; Guimarães et al., comunicação pessoal) do Domínio Rio Maria e com os dos TTG Transicionais do Cráton de Yilgarn (E) (Champion apud Almeida et al., 2010).

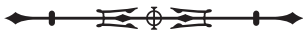


de média razão La/Yb da Suíte Guarantã, que é o grupo de maior representatividade daquela suíte.

O Leucogranodiorito Pantanal possui altas razões $\mathrm{Sr} / \mathrm{Y}$ (Tabela 2), e no diagrama Sr/Y versus Yb (Figura 14A) suas amostras situam-se, sem exceção, no campo dos LGdG com altas razões Sr/Y, que corresponde igualmente ao campo do grupo com altas razões La/Yb.

Já em relação aos leucogranitos potássicos do Domínio Rio Maria, o Leucogranodiorito Pantanal exibe marcantes distinções nos diagramas de Harker para os elementos maiores, em termos dos comportamentos de $\mathrm{Al}_{2} \mathrm{O}_{3}, \mathrm{CaO}, \mathrm{Na}_{2} \mathrm{O}$ e $\mathrm{K}_{2} \mathrm{O}$ e, embora haja certas semelhanças em termos de $\mathrm{MgO}$ e $\mathrm{TiO}_{2}$, fica evidente $\mathrm{o}$ acentuado contraste geoquímico entre o Leucogranodiorito Pantanal e os leucogranitos potássicos. Para os elementos-traço, essas diferenças são confirmadas pelo comportamento contrastante dos elementos litófilos (Figuras 10A-10C). Em termos dos ETR (Figuras 13C-13D), a principal diferença consiste na presença constante de marcante anomalia negativa de Eu nos leucogranitos potássicos e, no caso específico do Granito Mata Surrão, também pela ausência de concavidade no segmento de ETR pesados (Almeida et al., 2013).

De modo geral, as informações de campo, petrográficas e geoquímicas indicam grande semelhança entre o Leucogranodiorito Pantanal e os LGdG que ocorrem no Domínio Rio Maria e os TTG Transicionais do Cráton Yilgarn, mostrando que essas rochas foram muito provavelmente geradas por processos semelhantes e de fontes afins. Os conteúdos mais baixos de $\mathrm{K}_{2} \mathrm{O}$ e $\mathrm{Rb}$ e os valores menores da razão Rb/Sr sugerem que o Leucogranodiorito Pantanal é menos evoluído que os LGdG, podendo ter sofrido menor grau de diferenciação magmática ou resultar de um grau de fusão ligeiramente mais elevado. A correlação temporal entre o Leucogranodiorito Pantanal e a Suíte Guarantã e rochas similares de Rio Maria não pode ainda ser efetuada, porque não se dispõe da idade do primeiro. Nesse sentido, é muito importante definir se o Leucogranodiorito Pantanal é mesoarqueano e contemporâneo da Suíte Guarantã ou se, eventualmente, teve sua formação relacionada aos eventos neoarqueanos presentes apenas no Domínio Carajás. Em última análise, o comportamento geoquímico registrado deve-se ao fato de que o Leucogranodiorito Pantanal possui notável afinidade geoquímica com os leucogranodioritos e granitos da Suíte Guarantã e TTG Transicionais do Cráton Yilgarn, contrastando pela mesma razão dos leucogranitos potássicos de Rio Maria e granitos baixo Ca daquele cráton.

\section{CARACTERÍSTICAS GEOQUÍMICAS E PETROGÊNESE DO LEUCOGRANODIORITO PANTANAL}

Diversos autores têm contribuído para a identificação de diferentes grupos de leucogranitos arqueanos (Davis et al., 1994; Sylvester, 1994; Champion \& Sheraton, 1997; Champion \& Smithies, 1999; Leite et al., 1999; Moyen et al., 2003; Jayananda et al., 2006; Feio \& Dall'Agnol, 2012; Almeida et al., 2010, 2013), tendo sido distinguidos granitos cálcio-alcalinos, fortemente peraluminosos e alcalinos (Sylvester, 1994). Segundo Sylvester (1994), os contrastes geoquímicos indicam ambientes geodinâmicos distintos para a gênese desses granitos. Admite-se, em geral, que esses granitos sejam derivados de fusão parcial de granitoides similares às associações TTG arqueanas ou de rochas sedimentares ou, ainda, por meio da cristalização fracionada de magmas do tipo TTG (Condie \& Hunter, 1976; Cassidy et al., 1991; Kröner et al., 1991; Kröner \& Layer, 1992; Ridley, 1992; Sylvester, 1994; Davis et al., 1994). Entre as hipóteses alternativas, podem ser mencionadas a derivação a partir de fusão parcial de rochas intermediárias (Champion \& Sheraton, 1997; Jayananda et al., 2006; Feio \& Dall'Agnol, 2012) ou de granulitos residuais (Jayananda et al., 2006).

O Leucogranodiorito Pantanal é provavelmente intrusivo no Trondhjemito Colorado, com idade de $\sim 2,87$ Ga (Silva et al., comunicação pessoal, 2013). Apesar de sua idade ainda não estar definida, o contexto geológico e a similaridade geoquímica com os LGdG $(\sim 2,87 \mathrm{Ga})$ 
do Domínio Rio Maria permitem admitir como hipótese preliminar que o mesmo tenha idade mesoarqueana. Apresenta notável homogeneidade composicional e exibe teores de $\mathrm{SiO}_{2}$ altos e distribuídos em intervalo muito restrito (72,38-73,62\%; Tabela 2), o que sugere que processos de fracionamento não tiveram papel proeminente na evolução dessas rochas (Martin et al., 1997).

Diversos autores discutem a importância das razões $\mathrm{Sr} /$ e e La/Yb (Figura 14; Tabela 2) para a interpretação da origem de magmas granitoides (Drummond \& Defant, 1990; Martin, 1999; Almeida et al., 2010; Moyen, 2009; Feio \& Dall'Agnol, 2012). O alto coeficiente de partição
(Kd) do Sr no plagioclásio e a afinidade geoquímica de Yb e Y com a granada indicam que a presença de granada \pm hornblenda ou plagioclásio como fase fracionante dominante pode exercer forte influência na assinatura geoquímica de magmas granitoides gerados durante o Arqueano (Feio \& Dall'Agnol, 2012). A presença de um ou outro desses minerais no resíduo de fusão ou entre as fases fracionadas é atribuída geralmente às condições de pressão, que são determinantes para definir o campo de estabilidade de cada um deles. Entretanto, variações composicionais na fonte dos magmas também poderiam explicar os contrastes entre essas razões (Moyen, 2009).

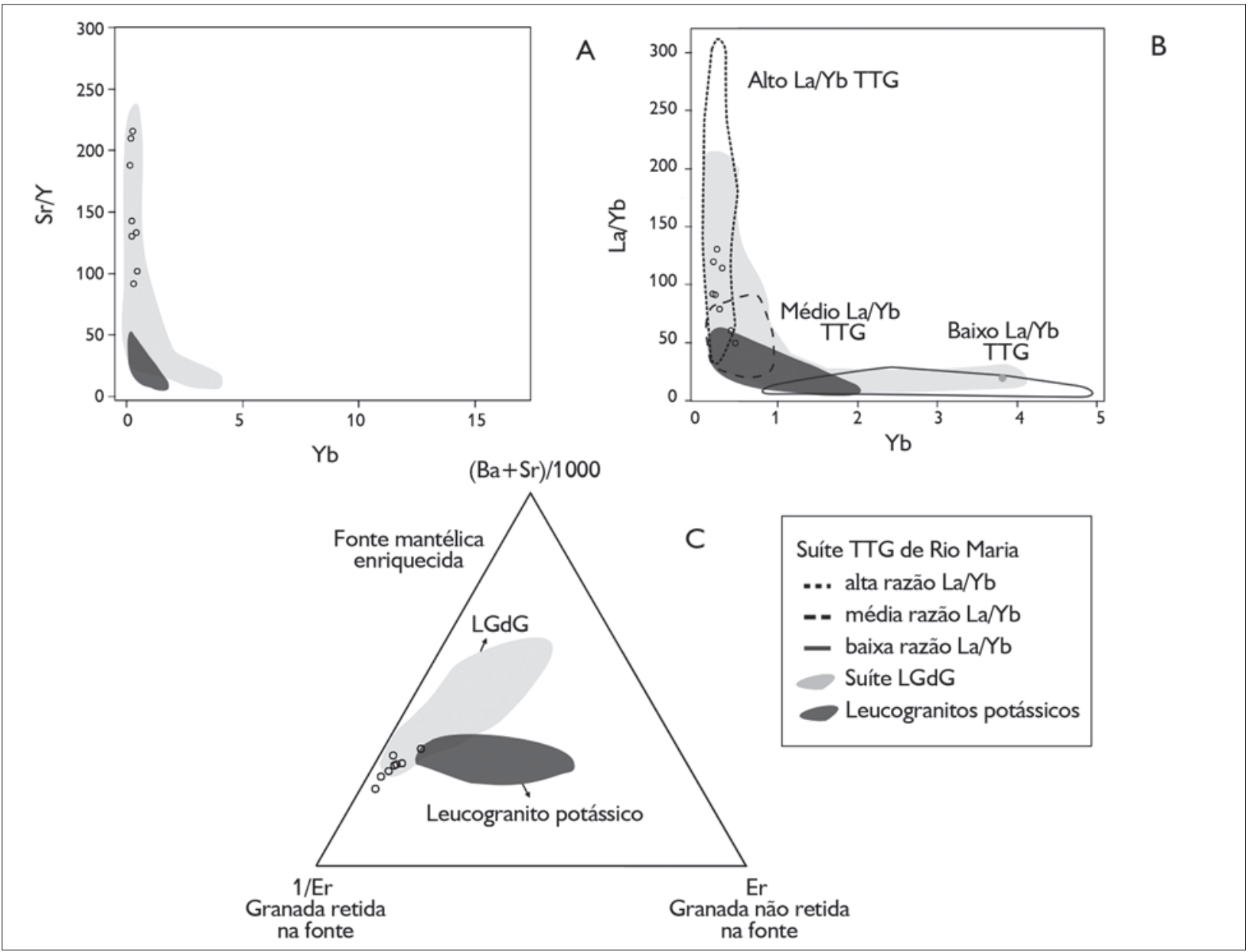

Figura 14. A) Diagrama Sr/Y versus Yb (Drummond \& Defant, 1990); B) diagrama La/Yb versus Yb (Martin, 1987); C) diagrama (Ba+ Sr)/1000-1/ Er-Er (Heilimo et al., 2010). Os campos dos leucogranodioritos-granitos e leucogranitos potássicos (Almeida et al., 2010; Feio \& Dall'Agnol, 2012) e TTG do Domínio Rio Maria (Almeida et al., 2011) foram plotados para comparação.

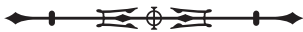


Os altos valores das razões Sr/Y e La/Yb (Figuras 14A-14B) no Leucogranodiorito Pantanal, assim como os padrões dos ETR semelhantes aos padrões típicos de rochas TTG, caracterizados pela ausência de anomalia de Eu e forte fracionamento dos ETR pesados, demonstram que na geração dessas rochas o plagioclásio não foi uma fase de fracionamento importante, ocorrendo o inverso com a granada. Além disso, os padrões de ETR (Figura 9) indicam que anfibólio também foi fracionado durante a evolução do magma. Adicionalmente, no diagrama triangular $(\mathrm{Ba}+\mathrm{Sr}) / 100-1 / \mathrm{Er}-\mathrm{Er}$ (Figura 14C), as amostras do Leucogranodiorito Pantanal evidenciam distribuição homogênea em termos do conteúdo de Er e se alinham no campo indicativo de retenção de granada na fonte, tal como observado para o Granito Bom Jesus, da área de Canaã dos Carajás (Feio \& Dall'Agnol, 2012). Tais evidências sugerem que essas rochas teriam sido derivadas de magmas gerados em condições equivalentes ao campo de estabilidade da granada, a pressões entre 10-15 kbar (Sen \& Dunn, 1994; Wolf \& Wyllie, 1994; Rapp \& Watson, 1995; Winther, 1996; Moyen \& Stevens, 2006; Almeida et al., 2011; Feio \& Dall'Agnol, 2012). As variações nas razões La/Yb e $\mathrm{Sr} / \mathrm{Y}$ nos TTG arqueanos dos diversos crátons, incluindo os TTG do Domínio Rio Maria (Figura 12B), têm sido sistematicamente utilizadas para estimativa das condições e processos de formação. No entanto, vale ressaltar que o Leucogranodiorito Pantanal não exibe variações expressivas nessas razões, ao contrário do que acontece nos TTG e na Suíte Guarantã de Rio Maria (Almeida et al., 2010, 2011).

Um dos modelos petrogenéticos propostos para explicar a origem de granodioritos envolveria a fusão discreta de crosta TTG (processos de anatexia), seguida de enriquecimento em elementos LILE (Martin et al., 1997). O Leucogranodiorito Pantanal exibe padrões que sugerem um possível vínculo genético com TTG ou, alternativamente, fracionamento durante a diferenciação magmática ou retenção nos resíduos de fusão das fontes de seu magma de fases semelhantes. No entanto, a fusão de rochas TTG deveria produzir líquido com significativa anomalia negativa de európio, devido à elevada probabilidade de retenção de plagioclásio no resíduo (Almeida et al., 2010). A ausência dessa anomalia no Leucogranodiorito Pantanal sugere que a hipótese de origem dessas rochas por fusão de magmas TTG não seria consistente. Além disso, fusões de rochas TTG não explicariam os altos valores de Ba e Sr presentes nessas rochas. Conclui-se, portanto, que essa hipótese pode ser descartada.

Outra hipótese discutida na literatura é que magmas granodioríticos podem ser produzidos pela interação entre magmas máficos hidratados, derivados do manto (sanukitoides) e crosta tonalítica. Segundo esse modelo, líquidos ricos em potássio derivados do manto liberam $\mathrm{H}_{2} \mathrm{O}$ $+\mathrm{K}_{2} \mathrm{O}$ para a crosta continental e, caso essa transferência seja acompanhada por elementos litófilos (por exemplo, $\mathrm{Ba}$ e Sr), poderia haver enriquecimento em tais elementos na crosta tonalítica, resultando em rochas similares aos granodioritos, mas preservando algumas características geoquímicas dos TTG (López et al., 2005).

Almeida et al. (2010, 2013) avaliaram criticamente as diferentes hipóteses para explicar os processos genéticos e evolução dos magmas dos LGdG e granitos potássicos. Tendo em vista a similaridade geoquímica com o LGdG, dois modelos serão discutidos na tentativa de esclarecer a gênese do Leucogranodiorito Pantanal. O primeiro modelo envolve processo de mixing entre magmas TTG e leucogranitos enriquecidos em Ba e Sr derivados de associação sanukitoide, e seria justificado em função das características dúbias do LGdG que apresentam feições típicas tanto de suítes TTG quanto de sanukitoides. Almeida et al. (2010) assumem que mixing em variadas proporções entre esses magmas poderia dar origem aos plútons da Suíte Guarantã e explicar suas variações composicionais. A área onde ocorrem os leucogranodioritos-granitos da Suíte Guarantã é também onde as rochas sanukitoides são mais enriquecidas em Ba e Sr, comparada com outras áreas do Domínio Rio Maria. A referida hipótese implicaria ainda que, naquela mesma área, líquidos trondhjemíticos deveriam ter se

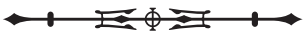


formado em torno de 2,87 Ga e sua ausência significaria que teriam sido inteiramente consumidos pelo processo de mixing (Almeida et al., 2010).

Para o Leucogranodiorito Pantanal, esse modelo é fragilizado na medida em que esta unidade aflora na porção leste do Subdomínio de Transição, onde, até o momento, não foram identificadas rochas de afinidade sanukitoide. Porém, Gabriel \& Oliveira (comunicação pessoal, 2013) reportam a ocorrência de rochas de alto $\mathrm{Mg}$, com idades de 2,87 a 2,88 Ga, que possuem fortes afinidades composicionais com aquelas das suítes sanukitoides do Domínio Rio Maria, na região de Água Azul do Norte, na porção centro-sul do Subdomínio de Transição. Apesar de essas ocorrências situarem-se geograficamente distantes do Leucogranodiorito Pantanal, o que torna improvável sua vinculação direta com os processos responsáveis por sua origem, ela demonstra a existência de magmas sanukitoides no Subdomínio de Transição. Adicionalmente, como o Trondhjemito Colorado, associação TTG dominante no Subdomínio de Transição, forneceu idade de $\sim 2,87 \mathrm{Ga}$ (Silva et al., 2010), ele poderia ser o líquido trondhjemítico envolvido na geração do magma do Leucogranodiorito Pantanal. Contudo, são necessários testes de modelamento e datações geocronológicas precisas das diferentes unidades para avaliar melhor essa hipótese. Por ora, ela permanece válida.

Um segundo modelo admite que fluidos enriquecidos em K, Sr e Ba derivados do manto metassomatizado seriam capazes de interagir com rochas TTG antigas ou com magmas TTG contemporâneos e modificá-los, até o ponto de gerar os LGdG (Almeida et al., 2013). A interação com rochas TTG formadas previamente implica admitir metassomatismo em grande escala e seria fortalecida devido à comum presença de zircões herdados, derivados de TTG antigos, na Suíte Guarantã. A segunda alternativa envolveria processos essencialmente magmáticos, sendo, porém, fragilizada pelo fato de não terem sido identificadas rochas TTG contemporâneas da Suíte Guarantã na sua principal área de ocorrência (Almeida et al., 2013).
A discussão de um modelo genético para o Leucogranodiorito Pantanal ainda é especulativa, pelo fato de não se dispor de dados conclusivos sobre as idades das principais associações granitoides do Subdomínio de Transição, tampouco sobre sua geoquímica isotópica. Contudo, assumindo-se a contemporaneidade entre - Leucogranodiorito Pantanal e a suíte LGdG ( 2,87 $\mathrm{Ga}$ ), a hipótese que envolve a interação entre fluidos enriquecidos em K, Sr e $\mathrm{Ba}$, derivados do manto metassomatizado, e rochas TTG contemporâneas, poderia ser adotada para o Leucogranodiorito Pantanal, na medida em que o Trondhjemito Colorado (2,87 Ga) é a unidade mais expressiva na sua área de ocorrência. As hipóteses de interação entre magmas trondhjemíticos e magmas sanukitoides (López et al., 2005; Almeida et al., 2010) tampouco podem ser descartadas.

\section{COMPARAÇÕES ENTRE O LEUCOGRANITO, HORNBLENDA-BIOTITA-GRANITO E OS GRANITOS SUBALCALINOS DO DOMÍNIO CARAJÁs}

Em função das características geoquímicas distintas dos leucogranitos em relação ao Leucogranodiorito Pantanal, optou-se por estabelecer comparações entre os mesmos e o magmatismo granítico subalcalino do tipo-A que se desenvolveu no Domínio Carajás (Subdomínio de Transição e Bacia Carajás) durante o Neoarqueano. Para tanto, as amostras analisadas do leucogranito serão comparadas com os granitos da Suíte Planalto ( 2,73 Ga; Feio et al., 2012, 2013), formados por sienogranitos e monzogranitos, com conteúdos variáveis de biotita e hornblenda, aflorantes na área de Canaã dos Carajás na porção norte do Subdomínio de Transição, e com o Granito Serra do Rabo ( 2,74 Ga; Sardinha et al., 2006), que compreende dois stocks graníticos constituídos por álcali feldspato-granitos e sienogranitos com hornblenda e biotita, que afloram na Bacia Carajás.

Conforme pode ser visualizado no diagrama $\mathrm{FeO}_{\mathrm{f}}$ $\left(\mathrm{FeO}_{\mathrm{t}}+\mathrm{MgO}\right.$ ) versus $\mathrm{Al}_{2} \mathrm{O}_{3}$ (Figura 12B), tanto as amostras do leucogranito quanto dos granitos Planalto e Serra do Rabo




incidem no campo dos granitos tipo-A reduzidos, justificando, assim, a tentativa de correlação entre essas unidades. $\bigcirc$ hornblenda-biotita-granito revela, nesse mesmo diagrama, maior afinidade com granitos tipo-A oxidados e, em razão disso, aproximar-se-ia mais dos granitoides da Suíte Vila Jussara. Em diagrama discriminante de granitos (Figura 12E, baseado em Sylvester, 1989), os leucogranitos plotam no campo das rochas alcalinas fortemente fracionadas, enquanto que os granitos Planalto e Serra do Rabo se concentram no campo das rochas alcalinas. $\bigcirc$ hornblenda-biotita-granito situa-se também no campo alcalino, estando, porém, mais próximo do seu limite com o campo cálcio-alcalino, com alguma analogia com a Suíte Vila Jussara.

De modo geral, nos diagramas de variação para elementos maiores e traço, os leucogranitos não ocupam campos coincidentes com os dos granitos mencionados, em função dos seus conteúdos de $\mathrm{SiO}_{2}$ (73-78\%) mais elevados quando comparados com os da Suíte Planalto $\left(\mathrm{SiO}_{2}=70\right.$ 75,62\%) e Granito Serra do Rabo ( $\left.\mathrm{SiO}_{2}=68-72,2 \%\right)$. Já as duas amostras de hornblenda-biotita-granito apresentam conteúdos de elementos maiores e traço similares aos dos granitos tipo Planalto, Vila Jussara e Serra do Rabo, tendendo, portanto, a plotar na maioria dos diagramas no campo definido por essas unidades e se distinguindo nesse aspecto dos leucogranitos. $\bigcirc$ hornblenda-biotita-granito poderia, talvez, corresponder a uma fácies menos evoluída, comagmática com os leucogranitos, porém a existência de descontinuidade composicional entre as duas variedades e o número limitado de amostras não permitem afirmar que se trate de uma única série magmática.

Em função de seu caráter mais evoluído, os leucogranitos são mais empobrecidos em elementos ferromagnesianos (por exemplo, $\mathrm{TiO}_{2}, \mathrm{FeO}_{\mathrm{t}}, \mathrm{MgO}$ e $\mathrm{CaO}$; Figuras 9A, 9C-9D, 9G). Possuem, ainda, conteúdos baixos de $\mathrm{Al}_{2} \mathrm{O}_{3}$ e $\mathrm{Na}_{2} \mathrm{O}$ e elevados de $\mathrm{K}_{2} \mathrm{O}$ e altas razões $\mathrm{K}_{2} \mathrm{O}$ / $\mathrm{Na}_{2} \mathrm{O}$ e FeO $/\left(\mathrm{FeO}_{t}+\mathrm{MgO}\right.$ ) (Figuras 9B, 9E-9F, 9H; Tabela 2), similares às dos granitos Planalto e Serra do Rabo.

Quando se compara o conteúdo dos elementostraço, os diagramas de Harker mostram que as amostras de leucogranito possuem teores muito reduzidos de $\mathrm{Ba}$ e Sr e elevados de Rb, Zr, Nb e Y (Figuras 10A-10F). O comportamento dos elementos $\mathrm{Sr}, \mathrm{Zr}$, Nb e Y é similar ao observado nos granitos Planalto e Serra do Rabo, embora os conteúdos de Sr e Zr sejam mais baixos no leucogranito, refletindo seus mais elevados valores de $\mathrm{SiO}_{2}$, e os de $\mathrm{Nb}$ e Y mais elevados do que os fornecidos pelos granitos Planalto e Serra do Rabo. Isso demonstra que o leucogranito, tal como os granitos escolhidos para comparação, é muito enriquecido em elementos de alto campo de força (HFSE), feição característica de granitos tipo-A. Já o comportamento de Ba e Rb é contrastante com o que se observa nos granitos Planalto e Serra do Rabo (alto Ba e Rb baixo a moderado; Figuras 10A-10B) e indica que, apesar das similaridades existentes, a evolução do leucogranito foi comandada por fracionamento de algumas fases distintas (possivelmente maior influência de feldspato potássico e menor de biotita no fracionamento). O hornblenda-biotita-granito apresenta, no entanto, conteúdos desses elementos similares aos observados nos granitos Planalto, Vila Jussara e Serra do Rabo, o que poderia ser indicativo de processos genéticos similares para esses granitoides.

Em relação aos ETR (Figura 15), o leucogranito caracteriza-se por exibir fraco enriquecimento dos ETR leves em relação aos pesados, baixos valores da razão $(\mathrm{La} / \mathrm{Yb})_{N}($ Tabela 2$)$, anomalia negativa extremamente acentuada de Eu, resultando em padrões 'asa-de-gaivota', típicos de granitos evoluídos. Os granitos Planalto e Serra do Rabo, por sua vez, são ligeiramente empobrecidos em ETR pesados e possuem anomalias negativas de Eu menos acentuadas, quando comparados aos leucogranitos (Figura 15). Há igualmente grande semelhança entre os padrões mostrados pelo hornblenda-biotita-granito (Figura 11) e aqueles da Suíte Planalto e Granito Serra do Rabo.

O que se deduz com base nesses dados é que o leucogranito apresenta assinatura geoquímica de granitos tipo-A reduzidos e, nesse sentido, possui grande afinidade com os granitos subalcalinos neoarqueanos do Domínio 


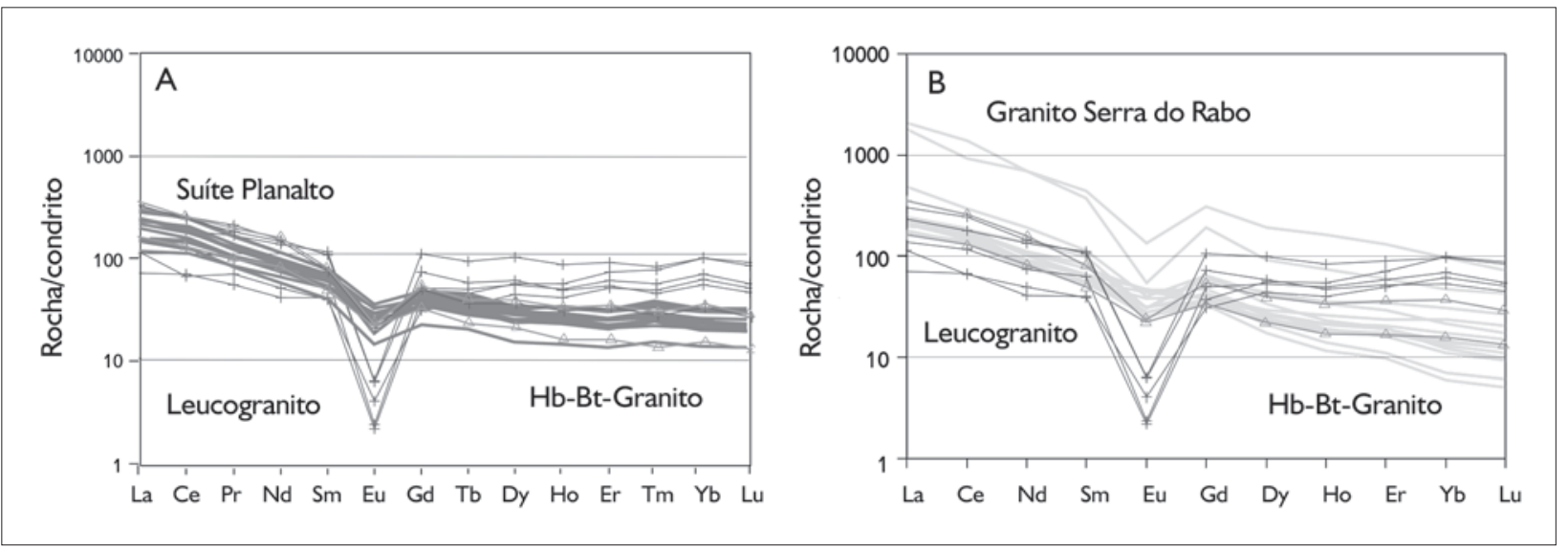

Figura 15. Padrões de ETR para comparação do leucogranito e hornblenda-biotita-granito com: A) Suíte Planalto (Feio et al., 2012); B) Granito Serra do Rabo (Sardinha et al., 2006) do Domínio Carajás. Valores normalizados em relação ao condrito (Evensen et al., 1978).

Carajás e diverge do Leucogranodiorito Pantanal e associações similares. Por outro lado, existem igualmente alguns contrastes geoquímicos entre o leucogranito e os granitos escolhidos para comparação, o que sugere que a fonte de seu magma e/ou processos de evolução magmática não foram inteiramente coincidentes com os dos granitos Planalto e Serra do Rabo. Apesar disso, admite-se como hipótese nesse estágio que o leucogranito foi originado no mesmo evento magmático que afetou o Domínio Carajás no Neoarqueano e gerou os granitos mencionados. O hornblenda-biotita-granito não pôde ser caracterizado de modo inteiramente conclusivo devido ao reduzido número de amostras, porém possui afinidade com granitos tipo-A e assemelha-se aos granitos neoarqueanos das suítes Planalto e Vila Jussara e ao Granito Serra do Rabo. Aparentemente, mostra caráter oxidado, tal como obervado nos granitoides Vila Jussara.

\section{IMPLICAÇÕES PETROGENÉTICAS PARA A GERAÇÃO DOS LEUCOGRANITOS}

Diversas origens têm sido discutidas na literatura para granitos tipo-A, isso devido à variabilidade da composição geoquímica dessas rochas. Loiselle \& Wones (1979) propõem que esses granitos seriam formados pelo fracionamento de álcali-basaltos derivados do manto, com ou sem interação crustal. Collins et al. (1982) sugerem que a fusão residual de granulitos poderia produzir granitos tipo-A. Anderson (1983) propôs que granitos tipo-A poderiam ser gerados por fusão parcial de quartzo-dioritos, tonalitos e granodioritos. Feio et al. (2012) assumem que a Suíte Planalto poderia ser gerada por fusão parcial de rochas granulíticas máficas a intermediárias de caráter tolético ou, menos provavelmente, por processos de assimilação e cristalização fracionada (AFC), envolvendo baixas taxas de assimilação da crosta inferior, formada por granulitos máficos, por um magma basáltico toleítico.

No entanto, considerando o caráter extremamente evoluído do leucogranito e a ausência de datação geocronológica e de dados isotópicos, nenhum modelo para explicar a origem dos magmas dos leucogranitos pode ser facilmente testado. Como não se dispõe de série magmática mais ampla do leucogranito, ou seja, de rochas cobrindo um intervalo maior de variação de sílica, não se pode concluir se o leucogranito deve seu caráter altamente evoluído a um fracionamento intenso devido a processos de diferenciação magmática ou a processos de fusão parcial com baixo grau de fusão.

O modelo clássico de Loiselle \& Wones (1979) é pouco adaptado ao contexto geológico da Província Carajás e o de Collins et al. (1982) foi severamente

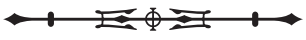


criticado (Creaser et al., 1991), não sendo aceito atualmente. $O$ modelo proposto por Feio et al. (2012) para explicar a origem do Granito Planalto não pode ser transposto diretamente para a geração do leucogranito, na medida em que não foi registrada a associação do mesmo com rochas charnoquíticas, mas não pode tampouco ser inteiramente descartado e deve ser reavaliado no futuro. Alternativamente, a fusão parcial de rochas quartzo-feldspáticas crustais poderia produzir granitoides alcalinos a cálcio-alcalinos que seriam supostamente metaluminosos a baixas pressões e peraluminosos a altas pressões (Frost \& Frost, 2011). Como o leucogranito ocorre associado ao Leucogranodiorito Pantanal, formado por rochas cálcio-alcalinas peraluminosas, este teria potencial para gerar o leucogranito. Em tese, a fusão em condições subsaturadas (dehidration melting) do Leucogranodiorito Pantanal poderia gerar o magma do leucogranito. Estudos experimentais mostram que o restito resultante da fusão parcial de granitoides cálcio-alcalinos em baixas pressões contém clinopiroxênio e plagioclásio (PatiñoDouce, 1997). A presença de plagioclásio no resíduo poderia explicar as anomalias de Eu do leucogranito, desde que se admita um baixíssimo grau de fusão. Essa hipótese deverá ser testada no futuro com a utilização de modelamento geoquímico e as informações advindas de datações geocronológicas e estudos isotópicos.

\section{CONCLUSÕES}

- O Leucogranodiorito Pantanal é composto por rochas de composição granodiorítica e textura porfirítica, fortemente foliadas (E-W), exibindo fenocristais ovalados de feldspato potássico. São leucogranodioritos cálcioalcalinos, fracamente peraluminosos, com altos conteúdos de Ba e Sr e possuem similaridade geoquímica com a Suíte Guarantã e leucogranodioritos e granitos afins do Domínio Rio Maria. Provavelmente essas rochas derivaram de processo e fontes semelhantes e, possivelmente, são contemporâneas. Os altos valores das razões La/Yb e
$\mathrm{Sr} / \mathrm{Y}$ mostram que granada teria sido fase fracionante importante na evolução desses magmas, ao contrário do plagioclásio, e sugerem que essas rochas foram derivadas de magmas gerados em condições equivalentes ao campo de estabilidade da granada, a pressões entre 10-15 kbar. Entretanto, a origem dessas rochas pode estar relacionada à interação em ambiente crustal entre fluidos enriquecidos em K, Sr e Ba, derivados do manto metassomatizado e o Trondhjemito Colorado (2,87 Ga). Nesse caso, a assinatura geoquímica do Leucogranodiorito Pantanal seria em grande parte herdada do referido trondhjemito, porém modificada pela adição de elementos litófilos.

- O leucogranito é constituído por rochas de composição monzogranítica intensamente deformadas que seccionam o Leucogranodiorito Pantanal em sua área-tipo. São granitos tipo-A reduzidos, afins geoquimicamente dos granitos Planalto e Serra do Rabo e, provavelmente, foram formados durante o evento neoarqueano que afetou o Domínio Carajás. A origem dos leucogranitos não pôde ser estabelecida, mas seu magma poderia ter sido formado a partir do baixíssimo grau de fusão em condições subsaturadas de rochas cálcio-alcalinas semelhantes ao Leucogranodiorito Pantanal ou, eventualmente, de rochas granulíticas similares às do Complexo Pium.

- Além desses granitoides, ocorrem ainda hornblendabiotita-granitos, os quais possuem afinidade com o tipo-A oxidado e podem estar relacionados aos granitoides Vila Jussara, de idade neoarqueana;

- Granitoides arqueanos com características geoquímicas semelhantes às daqueles do Domínio Rio Maria começam a ser identificados no Subdomínio de Transição (sanukitoides: granodioritos Água Azul e Água Limpa; Gabriel \& Oliveira, comunicação pessoal, 2013; associações TTG; Silva et al., comunicação pessoal, 2013; Santos et al., 2013). Os dados obtidos neste trabalho sobre o Leucogranodiorito Pantanal reforçam essa tendência. Contudo, o leucogranito identificado na área é provavelmente mais correlacionável ao magmatismo neoarqueano que afetou apenas o Domínio Carajás. 
Os resultados obtidos tendem a fortalecer a hipótese de que o Subdomínio de Transição represente uma extensão do Domínio Rio Maria, mas afetado por eventos de retrabalhamento crustal durante o Neoarqueano (Dall'Agnol et al., 2006).

\section{AGRADECIMENTOS}

Aos pesquisadores do Grupo de Pesquisa Petrologia de Granitoides, do Instituto de Geociências da Universidade Federal do Pará (GPPG-IG-UFPA), pelo apoio nas diversas etapas deste trabalho; ao Instituto de Geociências da Universidade Federal do Pará (IG-UFPA), pelo suporte técnico; à Coordenação de Aperfeiçoamento de Pessoal de Nível Superior (CAPES), pela concessão de bolsas de estudo (Mestrado - UFPA - P. A. Santos, M. F. B. Teixeira) e produtividade em pesquisa (R. Dall'Agnol) e por apoio financeiro (Processo n 484524/07-0). Este trabalho é uma contribuição para o projeto do Instituto Nacional de Ciência e Tecnologia (INCT) de Geociências da Amazônia (GEOCIAM; Conselho Nacional de Desenvolvimento Científico e Tecnológico/Ministério da Ciência e Tecnologia/ Fundação Amazônia Paraense de Amparo à Pesquisa CNPq/MCT/FAPESPA - Processo no 573733/2008-2) e para o projeto International Geoscience Programme Swedish International Development Cooperation Agency (IGCP-SIDA-599).

\section{REFERÊNCIAS}

ALMEIDA, J. A. C., R. DALL'AGNOL, S. B. DIAS \& F. J. ALTHOFF, 2010. Origin of the Archean leucogranodiorite-granite suites: evidence from the Rio Maria terrane and implications for granite magmatism in the Archean. Lithos 120(3-4): 235-257.

ALMEIDA, J. A. C., R. DALl'AGNOL, M. A. OlivEIRA, M. J. B. MACAMBIRA, M. M. PIMENTEL, O. T. RÄMÖ, F. V. GUIMARÃES \& A. A. S. LEITE, 2011. Zircon geochronology, geochemistry and origin of the TTG suites of the Rio Maria granite-greenstone terrane: implications for the growth of the Archean crust of the Carajás Province, Brazil. Precambrian Research 187(1-2): 201-221.

ALMEIDA, J. A. C., R. DALL'AGNOL \& A. A. S. LEITE, 2013. Geochemistry and zircon geochronology of the Archean granite suites of the Rio Maria granite-greenstone terrane, Carajás Province, Brazil. Journal of South American Earth Sciences 42: 103-126.
ALTHOFF, F. J., P. BARBEY \& A. M. BOULLIER, 2000. 2.8-3.0 Ga plutonism and deformation in the SE Amazonian craton: the Archean granitoids of Marajoara (Carajás Mineral Province, Brazil). Precambrian Research 104(3-4): 187-206.

ANDERSON, J. L., 1983. Proterozoic anorogenic granite plutonism of North America. Geological Society of America Memoirs 161: 133-154.

ARAÚJO, O. J. B., R. G. N. MAIA, X. S. JORGE JOÃO \& J. B. S. COSTA, 1988. A megaestrutura arqueana da Folha Serra dos Carajás. Anais do Congresso Latino-Americano de Geologia 7: 324-338.

ARAÚJO, O. J. B. \& R. G. N. MAIA, 1991. Programa de levantamentos geológicos básicos do Brasil: Serra dos Carajás, folha SB.22-Z-A, Estado do Pará. Texto explicativo: 1-164. DNPM/CPRM, Brasília.

BARKER, F., 1979. Trondhjemites: definition, environment and hypotheses of origin. In: F. BARKER (Ed.): Trondhjemites, dacites and related rocks: 1-12. Elsevier, Amsterdam.

BARROS, C. E. M. \& R. DALL'AGNOL, 1994. Deformação de rochas granitóides em regime dúctil: o exemplo do Gnaisse Estrela, região de Carajás. Revista Brasileira de Geociências 24(3): 129-138.

BARROS, C. E. M., R. DALL'AGNOL, P. BARBEY \& A. M. BOULLIER, 1997. Geochemistry of the Estrela Granite Complex, Carajás region, Brazil: an example of an Archaean A-type granitoid. Journal of South American Earth Sciences 10(3-4): $321-330$

BARROS, C. E. M., P. BARBEY \& A. M. BOULLIER, 2001. Role of magma pressure, tectonic stress and crystallization progress in the emplacement of the syntectonic A-type Estrela Granite Complex (Carajás Mineral Province, Brazil). Tectonophysics 343(1-2): 93-109.

BARROS, C. E. M., A. S. SARDINHA, J. P. O. BARBOSA, M. J. B. MACAMBIRA, P. BARBEY \& A. M. BOULLIER, 2009. Structure, petrology, geochemistry and zircon $\mathrm{U} / \mathrm{Pb}$ and $\mathrm{Pb} / \mathrm{Pb}$ geochronology of the synkinematic Archean (2.7 Ga) A-type granites from the Carajás Metallogenic Province, northern Brazil. The Canadian Mineralogist 47: 1423-1440.

BOWDEN, P., R. A. BATCHELOR, B. W. CHAPPELL, J. DIDIER \&J. LAMEYRE, 1984. Petrological, geochemical and source criteria for the classification of granitic rocks: a discussion. Physics of the Earth and Planetary Interiors 35(1-3): 1-11.

CASSIDY, K. F., M. E. BARLEY, D. I. GROVES, C. S PERRING \& J. A. HALLBERG, 1991. An overview of the nature, distribution and inferred tectonic setting of granitoids in the late-Archaean Norseman-Wiluna Belt. Precambrian Research 51(1-4): 51-83.

CHAMPION, D. C. \& J. W. SHERATON, 1997. Geochemistry and $\mathrm{Nd}$ isotope systematics of Archaean granites of the Eastern Goldfields, Yilgarn Craton, Australia: implications for crustal growth processes. Precambrian Research 83(1-3): 109-132.

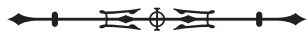


CHAMPION, D. C. \& R. H. SMITHIES, 1999. Archaean granites of the Yilgarn and Pilbara cratons, Western Australia: secular changes. In: B. BARBARIN, W. E. STEPHENS, B. BONIN, J.-L. BOUCHEZ, D. B. CLARKE, M. CUNEY \& H. MARTIN (Eds.): Abstracts of the Fourth Hutton Symposium on the Origin of Granites and Related Rocks: 1-137. BRGM, Clermond-Ferrant.

CHAMPION, D. C. \& R. H. SMITHIES, 2003. Archaean granites. In: P. BLEVIN, M. JONES \& B. CHAPPELL (Eds.): Magmas to mineralisation: the Ishihara Symposium: 13-18. Geoscience Australia, Canberra.

COLLINS, W. J., S. D. BEAMS, A. J. R. WHITE \& B. W. CHAPPELL, 1982. Nature and origin of A-type granites with particular reference to southeastern Australia. Contributions to Mineralogy and Petrology 80(2): 189-200

CONDIE, K. C., 1993. Chemical composition and evolution of the upper continental crust: contrasting results from surface samples and shales. Chemical Geology 104(1-4): 1-37.

CONDIE, K. C. \& D. R. HUNTER, 1976. Trace element geochemistry of Archean granitic rocks from the Barberton region, South Africa. Earth and Planetary Science Letters 29(2): 389-400.

CREASER, R. A., R. C. PRICE \& R. J. WORMALD, 1991 A-type granites revisited: assessment of a residual-source model. Geology 19(2): 163-166.

DALL'AGNOL, R., M. A. OLIVEIRA, J. A. C. ALMEIDA, F. J. ALTHOFF, A. A. S. LEITE, D. C. OLIVEIRA \& C. E. M. BARROS, 2006. Archean and Paleoproterozoic granitoids of the Carajás metallogenetic province, eastern Amazonian Craton. Symposium on Magmatism, Crustal Evolution, and Metallogenesis of the Amazonian Craton 1: 97-150.

DALL'AGNOL, R. \& D. C. OLIVEIRA, 2007. Oxidized, magnetiteseries, rapakivi-type granites of Carajás, Brazil: implications for classification and petrogenesis of A-type granites. Lithos 93(3-4): 215-233.

DAVIS, W. J., B. J. FRYERS \& J. E. KING, 1994. Geochemistry and evolution of late Archean plutonism and its significance to the tectonic development of the Slave craton. Precambrian Research 67(3-4): 207-241.

DE LA ROCHE, H., J. LETERRIER, P. GRANDCLAUDE \& $M$. MARCHAL, 1980. A classification of volcanic and plutonic rocks using $R_{1}-R_{2}$-diagram and major-element analyses - its relationships with current nomenclature. Chemical Geology 29(1-4): 183-210.

DEBON, F. \& P. LE FORT, 1983. A chemical-mineralogical classification of common plutonic rocks and associations. Transactions of the Royal Society of Edinburgh, Earth Sciences 73(3): 135-149.

DRUMMOND, M. S. \& M. J. DEFANT, 1990. A model for Trondhjemite-Tonalite-Dacite Genesis and crustal growth via slab melting. Archaean to modern comparisons. Journal of Geophysical Research: Solid Earth 95(B13): 21503-21521.
DUARTE, K. D., E. D. PEREIRA, R. DALL'AGNOL \&J. M. LAFON, 1991. Geologia e geocronologia do granito Mata Surrão - Sudoeste de Rio Maria (PA). Anais do Simpósio de Geologia da Amazônia 3: 7-20.

DUARTE, K. D. \& R. DALL'AGNOL, 1996. Gelogia e Geoquímica do Leucogranito Arqueano potássico Mata Surrão, Terreno GranitoGreenstone de Rio Maria, Pará. Boletim IG-USP. Publicação Especial 18: $113-115$

EVENSEN, N. M., P. J. HAMILTON \& R. K. O'NIONS, 1978. Rare-earth abundances in chondritic meteorites. Geochimica et Cosmochimica Acta 42(8): 1199-1212.

FEIO, G. R. L. \& R. DALL'AGNOL, 2012. Geochemistry and petrogenesis of the granites from the Canaã dos Carajás area, Carajás province, Brazil: implications for the origin of Archean granites. Lithos 154: 33-52.

FEIO, G. R. L., R. DALL'AGNOL, E. L. DANTAS, M. J. B. MACAMBIRA, A. C. B. GOMES, A. S. SARDINHA, D. C. OLIVEIRA, R. D. SANTOS \& P. A. SANTOS, 2012. Geochemistry, geochronology, and origin of the Neoarchean Planalto Granite suite, Carajás, Amazonian craton: A-type or hydrated charnockitic granites? Lithos 151: 57-73.

FEIO, G. R. L., R. DALL'AGNOL, E. L. DANTAS, M. J. B. MACAMBIRA, J. O. S. SANTOS, F. J. ALTHOFF \& J. E. B. SOARES, 2013. Archean granitoid magmatism in the Canaã dos Carajás area: implications for crustal evolution of the Carajás province, Amazonian craton, Brazil. Precambrian Research 227: 157-185.

FROST, C. D. \& B. R. FROST, 2011. On ferroan (A-type) granitoids: their compositional variability and modes of origin. Journal of Petrology 52(1): 39-53.

GABRIEL, E. O., D. C. OliveIRA \& M. A. GALARZA, 2010. Petrografia e geocronologia de granitoides do Complexo Xingu da região nordeste de Água Azul do Norte, Província Mineral de Carajás. Anais do Congresso Brasileiro de Geologia 45: 1 CD-ROM.

GOMES, A. C. B. \& R. DALL'AGNOL, 2007. Nova associação tonalítica-trondhjemítica neoarqueana na região de Canaã dos Carajás: TTGS com altos conteúdos de Ti, Zr e Y. Revista Brasileira de Geociências 37(1): 182-193.

GUiMARÃES, F. V. G., R. DALL'AGNOL, D. C. OliveIRA, A. C. SILVA, M. F. T. TEIXEIRA \& P. A. SANTOS, 2012. Geologia preliminar da porção leste do Subdomínio de Transição da Província Carajás PA. Anais do Congresso Brasileiro de Geologia 46: 1 CD-ROM.

HANSON, G. N., 1978. The application of trace elements to the petrogenesis of igneous rocks of granitic composition. Earth and Planetary Science Letters 38(1): 26-43.

HEILIMO, E., J. HALLA \& P. HÖLTTÄ, 2010. Discrimination and origin of the sanukitoid series: geochemical constraints from the Neoarchean western Karelian Province (Finland). Lithos 115(1-4): 27-39.




HUHN, S. B., M. J. B. MACAMBIRA \& R. DALL'AGNOL, 1999. Geologia e Geocronologia Pb-Pb do Granito Alcalino Arqueano Planalto, Região da Serra do Rabo, Carajás - PA. Boletim de Resumos Expandidos do Simpósio de Geologia da Amazônia 6(1): 463-466.

JAYANANDA, M., D. CHARDON, J.-J. PEUCAT \& R. CAPDEVILA, 2006. 2.61 Ga potassic granites and crustal reworking in the western Dharwar craton, southern India: tectonic, geochronologic and geochemical constraints. Precambrian Research 150(1-2): 1-26.

KRETZ, R., 1983. Symbols for rock-forming minerals. American Mineralogist 68: 277-279.

KRÖNER, A., G. R. BYERLY \& D. R. LOWE, 1991. Chronology of early Archaean granite-greenstone evolution in the Barberton Mountainland, South Africa, based on precise dating by single zircon evaporation. Earth and Planetary Science Letters 103(1-4): 41-54.

KRÖNER, A. \& P. W. LAYER, 1992. Crust formation and plate motion in the early Archean. Science 256(5062): 1405-1411.

LE MAITRE, R. W. (Ed.), 2002. Igneous rocks: a classification and glossary of terms: 1-193. Cambridge University Press, London.

LEITE, A. A. S., R. DALL'AGNOL \& F. J. ALTHOFF, 1999. Geoquímica e aspectos petrogenéticos do Granito Xinguara, terreno Granito-Greenstone de Rio Maria - Cráton Amazônico. Revista Brasileira de Geociências 29(3): 429-436.

LEITE, A. A. S., R. DALl'AGNOL, M. J. B. MACAMBIRA \& F. J. ALTHOFF, 2004. Geologia e geocronologia dos granitóides arqueanos da região de Xinguara-PA e suas implicações na evolução do terreno granito-greenstone de Rio Maria, Cráton Amazônico. Revista Brasileira de Geociências 34(4): 447-458.

LOISELLE, M. C. \& D. WONES, 1979. Characteristics and origin of anorogenic granites. Abstracts of the Geological Society of America 11: 1-468.

LÓPEZ, S. , A. CASTRO \& A. GARCÍA-CASCO, 2005. Production of granodiorite melt by interaction between hydrous mafic magma and tonalitic crust. Experimental constraints and implications for the generation of Archaean TTG complexes. Lithos 79(1-2): 229-250.

MANIAR, P. D. \& P. M. PICCOLI, 1989. Tectonic discrimination of granitoids. Geological Society of America Bulletin 101(5): 635-643.

MARTIN, H., 1987. Petrogenesis of Archaean trondhjemites, tonalites, and granodiorites from eastern Finland: major and trace element geochemistry. Journal of Petrology 28(5): 921-953.

MARTIN, H., 1994. The Archean grey gneisses and the gneisses of continental crust. In: K. C. CONDIE (Ed.): Archean crustal evolution: 205-259. Elsevier (Developments in Precambrian Geology, 11), Amsterdam.
MARTIN, H., 1999. Adakitic magmas: modern analogues of Archaean granitoids. Lithos 46(3): 411-429.

MARTIN, H., J. J. PEUCAT, P. SABATÉ \& J. C. CUNHA, 1997. Crustal evolution in the early Archaean of South America: example of the Sete Voltas Massif, Bahia State, Brazil. Precambrian Research 82(1-2): 35-62.

MICROSOFT, 2012. Microsoft Office Excel Help. PEARSON Excel - Office.com. Disponível em: <http://office.microsoft.com/ pt-br/excel-help/pearson-HP005209210.aspx>. Acesso em: 8 novembro 2013.

MOYEN, J. F., 2009. High Sr/Y and La/Yb ratios: the meaning of the "adakitic signature". Lithos 112(3-4): 556-574.

MOYEN, J. F., H. MARTIN, M. JAYANANDA \& B. AUVRAY, 2003. Late Archaean granites: a typology based on the Dharwar Craton (India). Precambrian Research 127(1-3): 103-123.

MOYEN, J. F. \& G. STEVENS, 2006. Experimental constraints on TTG petrogenesis: implications for Archean geodynamics. In: K. BENN, J.C. MARESCHAL \& K. C. CONDIE (Eds.): Archean geodynamics and environments: 149-178. American Geophysical Union, Washington.

NASA LANDSAT PROGRAM, 2003. Landsat ETM+ scene L71008058_05820031026, SLC-Off, USGS, Sioux Falls, 10/26/2003.

O'CONNOR, J. T., 1965. A classification for quartz-rich igneous rocks based on feldspar ratios. United States Geological Survey Professional Paper 525B: 79-84.

OLIVEIRA, D. C., P. J. L. SANTOS, E. O. GABRIEL, D. S RODRIGUES, A. C. FARESIN, M. L. T. SILVA, S. D. SOUSA, R. V. SANTOS, A. C. SILVA, M. C. SOUZA, R. D. SANTOS \& M. J. B. MACAMBIRA, 2010. Aspectos geológicos e geocronológicos das rochas magmáticas e metamórficas da região entre os municípios de Água Azul do Norte e Canaã dos Carajás - Província Mineral de Carajás. Anais do Congresso Brasileiro de Geologia 45: 1 CD-ROM.

OLIVEIRA, M. A., R. DALL'AGNOL, F. J. ALTHOFF \& A. A. S. LEITE, 2009. Mesoarchean sanukitoid rocks of the Rio Maria GraniteGreenstone Terrane, Amazonian craton, Brazil. Journal of South American Earth Sciences 27(2-3): 146-160.

OLIVEIRA, M. A., R. DALL'AGNOL \& B. SCAILLET, 2010. Petrological constraints on crystallization conditions of Mesoarchean sanukitoid rocks, southeastern Amazonian Craton, Brazil. Journal of Petrology 51(10): 2121-2148.

PATIÑO-DOUCE, A. E., 1997. Generation of metaluminous A-type granites by low-pressure melting of calc-alkaline granitoids. Geology 25(8): 743-746.

RAPP, R. P. \& E. B. WATSON, 1995. Dehydration melting of metabasalt at 8-32 kbar: implications for continental growth and crust-mantle recycling. Journal of Petrology 36(4): 891-931. 
RIDLEY, J. R., 1992. The thermal causes and effects of voluminous, late Archean monzogranite plutonism. In: J. E. GLOVER \& S. E. $\mathrm{HO}$ (Eds.): The archean, terrains, processes and metallogeny: 22: 275-285. The University of Western Australia, Perth.

SANTOS, J. O. S., L. A. HARTMANN, H. E. GAUDETTE, D. I. GROVES, N. J. MCNAUGHTON \& I. R. FLETCHER, 2000. A new understanding of the provinces of the Amazon craton based on integration of field mapping and $\mathrm{U}-\mathrm{Pb}$ and $\mathrm{Sm}-\mathrm{Nd}$ geochronology. Gondwana Research 3(4): 453-488.

SANTOS, J. O. S., L. A. HARTMANN, S. R. RIKER, M. M. SOUZA, M. E. ALMEIDA \& N. J. MCNAUGHTON, 2006. A compartimentação do Cráton Amazonas em províncias: avanços ocorridos no período 2000-2006. Resumo Expandido do Simpósio de Geologia da Amazônia 9: 1 CD-ROM.

SANTOS, P. A., M. F. B. TEIXEIRA, R. DALL'AGNOLL \& A. V. GUIMARÃES, 2013. Geologia, petrografia e geoquímica da associação Tonalito-Trondhjemito-Granodiorito (TTG) do extremo leste do Subdomínio de Transição, Província Carajás, Pará. Boletim do Museu Paraense Emílio Goeldi. Ciências Naturais 8(3): 257-290.

SARDINHA, A. S., C. E. M. BARROS \& R. KRYMSKY, 2006. Geology, geochemistry, and U-Pb geochronology of the Archean (2.74 Ga) Serra do Rabo granite stocks, Carajás Metallogenetic Province, northern Brazil. Journal of South American Earth Sciences 20(4): 327-339.

SEN, C. \& T. DUNN, 1994. Dehydration melting of a basaltic composition amphibolite at 1.5 and 2.0 GPa: implications for the origin of adakites. Contributions to Mineralogy and Petrology 117(4): 394-409.

SHAND, S. J., 1950. Eruptive rocks, their genesis, composition, classification and their relation to ore-deposits: 1-488. Thomas Murby, London.

SILVA, A. C., D. C. OliveirA \& M. J. B. MACAMBIRA, 2010. Individualização e geocronologia de granitóides do Complexo Xingu, região de Vila Jussara, município de Água Azul do Norte - PA, Província Mineral de Carajás. Anais do Congresso Brasileiro de Geologia 45: $1 \mathrm{CD}-\mathrm{ROM}$.

SMITH, J. V., 1974. Feldspar minerals: crystal structures, physical, chemical, and microtextural properties: 1: 1-627. Springer-Verlag, New York.
SOUZA, M. C., D. C. OliveirA, M. J. B. MACAMBIRA \& M. A. T. GALARZA, 2010. Geologia, petrografia e geocronologia do granito de alto K da região de Velha Canadá, município de Água Azul do Norte - Província Mineral de Carajás. Anais do Congresso Brasileiro de Geologia 45: 1 CD-ROM.

STRECKEISEN, A., 1976. To each plutonic rock its proper name. Earth-Science Reviews 12(1): 1-33.

SYLVESTER, P. J., 1989. Post-collisional alkaline granites. The Journal of Geology 97(3): 261-280.

SYLVESTER, P. J., 1994. Archean granite plutons. In: K. C. CONDIE (Ed.): Archean crustal evolution: 261-314. Elsevier (Developments in Precambrian Geology, 11), Amsterdam.

TASSINARI, C. C. G. \& M. J. B. MACAMBIRA, 2004. A evolução tectônica do Cráton Amazônico. In: V. MANTESSO NETO, A. BARTORELLI, C. D. R. CARNEIRO \& B. B. BRITO-NEVES (Orgs.): Geologia do continente Sul-americano: evolução da obra de Fernando Flávio Marques de Almeida: 471-486. BECA, São Paulo.

VASQUEZ, M. L., L. R. ROSA-COSTA, C. G. SILVA, P. F. RICCI, J. O. BARBOSA, E. L. KLEIN, E. S. LOPES, E. B. MACAMBIRA, C. L. CHAVES, J. M. CARVALHO, J. G. OLIVEIRA, G. C. ANJOS \& H. R. SILVA, 2008. Geologia e recursos minerais do Estado do Pará: Sistema de Informações Geográficas - SIG: Texto explicativo dos mapas geológico e tectônico e de recursos minerais do Estado do Pará. In: M. L. VASQUES \& L. T. ROSA-COSTA (Orgs.): Escala 1:1.000.000: 118-121. CPRM, Belém.

WHALEN, J. B., K. L. CURRIE \& B. W. CHAPPEL, 1987. A-type granites: geochemical characteristics, discrimination and petrogenesis. Contributions to Mineralogy and Petrology 95(4): 407-419.

WINTHER, K. T., 1996. An experimentally based model for the origin of tonalitic and trondhjemitic melts. Chemical Geology 127(1-3): 43-59.

WOLF, M. B. \& P. J. WYLLIE, 1994. Dehydration-melting of amphibolite at $10 \mathrm{kbar}$ : the effects of temperature and time. Contributions to Mineralogy and Petrology 115(4): 369-383.

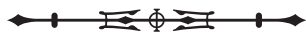


